RESEARCH ARTICLE

\title{
Misaccounting for endogeneity: The peril of relying on the Heckman two-step method without a valid instrument
}

\author{
Sarah E. Wolfolds ${ }^{1}$ | Jordan Siegel ${ }^{2}$
}

${ }^{1}$ Charles H. Dyson School of Applied

Economics \& Management, Cornell SC Johnson

College of Business, Ithaca, New York

${ }^{2}$ Ross School of Business, University of Michigan, Ann Arbor, Michigan

\section{Correspondence}

Sarah E. Wolfolds, Charles H. Dyson School of Applied Economics \& Management, Cornell SC Johnson College of Business, 375E Warren Hall, Ithaca, NY 14853.

Email: sew276@cornell.edu

\section{Funding information}

Cornell University Dyson School of Applied Economics and Management, University of

Michigan Ross School of Business
Research Summary: Strategy research addresses endogeneity by incorporating econometric techniques, including Heckman's two-step method. The economics literature theorizes regarding optimal usage of Heckman's method, emphasizing the valid exclusion condition necessary in the first stage. However, our meta-analysis reveals that only 54 of 165 relevant papers published in the top strategy and organizational theory journals during 1995-2016 claim a valid exclusion restriction. Without this condition being met, our simulation shows that results using the Heckman method are often less reliable than OLS results. Even where Heckman is not possible, we recommend that other rigorous identification approaches be used. We illustrate our recommendation to use a triangulation of identification approaches by revisiting the classic global strategy question of the performance implications of cross-border market entry through greenfield or acquisition.

Managerial Summary: Managers make strategic decisions by choosing the best option given the particular circumstances of their firm. However, researchers had previously not taken into consideration these circumstances when evaluating the outcome of that choice. The Heckman method importantly addresses this situation, but requires that the researcher have some variable that effects the best option for the firm, but not the outcome. We show that researchers frequently do not utilize such a variable, and demonstrate that the Heckman method can exacerbate estimation issues in this case. We then provide an approach that researchers can use to address the challenge of determining the outcome of a strategic decision, and illustrate it with an empirical examination of the performance implications of cross-border market entry through greenfield or acquisition. 


\section{KEYWORDS}

entry mode, foreign investment, Heckman correction, selection bias, two-step estimator

\section{1 | INTRODUCTION}

Strategy research has recently encouraged the use of advanced econometric techniques such as the Heckman two-step method. Though econometric methods can be vital to draw conclusions from nonrandom data, understanding the theoretical underpinnings, and especially the assumptions, that go into them is crucial, particularly given that newer programming languages contain precoded packages and routines that require little knowledge of the model's mechanics. Recent papers in Strategic Organization have even provided STATA code to perform Heckman's two-step method. Bascle (2008) and Hamilton and Nickerson (2003) both provide concise presentations of the Heckman two-step method as it applies to strategic management research, whereas Certo, Busenbark, Woo, and Semadeni (2016) provide guidelines for determining when the Heckman method is not necessary.

A key tenet of the strategy field is that firms are heterogeneous and that managers will choose a strategy based on this heterogeneity. For example, managerial decisions are often endogenous to firm performance (Bascle, 2008) and, similarly, the resource-based view asserts that, to obtain competitive advantage, firms ought to diversify and develop products based on their unique resources. In other words, "endogeneity bias is a concern only when firms have some unobservable (to the researcher) advantage or disadvantage that influences the strategy they choose" (Hamilton \& Nickerson, 2003, p. 65). Because much of strategy research stipulates that a strategy or resource needs to be both inimitable and uniquely based on firm characteristics to sustain a competitive advantage, it seems reasonable to conclude that endogeneity is a widespread concern in this area.

Thus, the Heckman method can be especially useful in strategic management research, where endogeneity is a frequent problem to solve. However, the Heckman method should not be used without careful consideration of its appropriateness and of the ability to implement it accurately. Our paper analyzes a way in which the Heckman method is often implemented that lowers its reliability: without a valid exclusion restriction in the first stage, described in Section 2. In Section 3, we use simulation analysis to illustrate how the Heckman method compares to OLS when used with and without a valid exclusion restriction, finding that OLS performs better than the Heckman method without a valid exclusion restriction when the assumption that the errors follow a bivariate normal distribution fails to hold. This is a relevant concern because the assumption that large sample size will assuage concerns of nonnormality fails in a majority of cases due to lumpiness and asymmetry in data (Micceri, 1989). We then illustrate the prevalence of this issue via a meta-analysis of the strategy and organizational theory literatures in Section 4, showing that the Heckman method continues to be used without a valid exclusion restriction. Finally, in Section 5, we revisit a classic global strategy question, namely whether there is an average performance advantage between greenfield-based foreign entry and acquisition-based foreign entry, to demonstrate the triangulation of approaches we suggest to future researchers. Shaver (1998) utilized the same question to introduce the Heckman method to the strategy literature; we approach the question with different data to provide practical evidence on this important methodological point. Section 6 concludes and provides suggestions for future researchers. 
In recent years the strategy and organizational theory literatures have increasingly employed the Heckman two-step method, and our empirical work, supported through our simulation analysis, suggests that a thorough understanding of the context and of the importance of an exclusion restriction could spur discovery of additional instruments that allow for better application of the Heckman method.

\section{I SELECTION BIAS AND HECKMAN'S METHOD}

"Heckman correction has profoundly changed applied research in the social and behavioral sciences" (Bascle, 2008, p. 286).

\section{1 | Motivation for Heckman correction}

Empirical work often attempts to establish a causal relationship, where researchers can conclude that $x$ causes $y$. Generally, $x$ can be said to cause $y$ if the following three conditions hold: (1) $y$ follows $x$; (2) $y$ changes as $x$ changes; and (3) there does not exist another cause that can eliminate the relationship between $x$ and $y$ (Antonakis, Bendahan, Jacquart, \& Lalive, 2014; Holland, 1986; Kenny, 1979). Failure of the third condition occurs if $x$ is endogenous, or if $x$ does not vary randomly and independently.

Endogeneity can occur for a number of reasons, including omitting a regressor, simultaneity, and selection bias, among others (Antonakis et al., 2014). This paper concerns the issue of selection bias. Many classic examples of selection bias come from labor economics. Consider estimating the effect of college education on earnings. The key issue is that those that self-select to attend college may have other characteristics that are correlated and affect earnings, such as ability. If one can control directly for these other characteristics (by including them as regressors), then we have a situation of selection on observable variables and we can get a consistent estimate. When selection instead occurs on unobservable variables, the approach is more challenging. The Heckman method presented in the next section is one way to address this issue.

The Heckman two step method applies to two different types of selection: truncation and treatment effects (Greene, 2008). Truncation is where only the outcomes of treated observations are observable, whereas we observe outcomes for both the treated and untreated populations in a treatment effects model. For example, we observe the number of children for both those that attend college and those that do not, so evaluating the effect of college on family size suffers from treatment effects. On the other hand, determining how wage depends on marital status and other demographic characteristics will suffer from truncation as we will not observe the shadow wage for those that do not enter the workforce.

\section{2 | Heckman's two-step method for sample selection}

Heckman's 1979 paper advanced a method, known as the two-step or correction method, that uses simple least squares estimation on a nonrandomly selected sample while avoiding sample specification bias (Heckman, 1979). In brief, the Heckman two-step method presented below controls for selection by first modeling the decision to participate with a probit model on individual characteristics. In the second step, the outcome variable is regressed using least squares on the exogenous characteristics and the fitted values from the selection equation, which are in a function called the inverse 
Mills ratio or Heckman's lambda (Verbeek, 2000). ${ }^{1}$ The first step is referred to as the selection equation; the second is the outcome equation.

Let $Y_{1}^{\prime}$ and $Y_{2}^{\prime}$ be latent variables, where the data-generating process is:

$$
\begin{aligned}
& Y_{1 i}^{\prime}=X_{i} \beta+u_{i} \\
& Y_{2 i}^{\prime}=Z_{i} \lambda+v_{i} .
\end{aligned}
$$

The errors, $u_{i}$ and $v_{i}$, are assumed to follow a bivariate normal distribution.

Consider that selection occurs such that $Y_{1}$ and $Y_{2}$ are the observed variables, where:

$$
\begin{aligned}
& Y_{1 i}=Y_{1 i}^{\prime} \text { and } Y_{2 i}=1 \text { if } Y_{2 i}^{\prime}>t \\
& \text { and } Y_{1 i} \text { not observed, } Y_{2 i}=0 \text { if } Y_{2 i}^{\prime} \leq t .
\end{aligned}
$$

Thus, if the latent variable, $Y_{2 i}{ }^{\prime}$, is greater than some threshold, $t$, the observation will be selected, such that $Y_{2 i}=1$ and the latent outcome variable, $Y_{1}^{\prime}$, will actually be observed in $Y_{1 i}$.

Using the distributional assumptions, that $u_{i}=p v_{i}+e_{i}$, Heckman then plugs in for the error term to rewrite the data-generating process as:

$$
Y_{1 i}=X_{i} \beta+p v_{i}+e_{i}
$$

A regression of $Y_{1 i}$ on $X_{i}$ would then omit the selection effect, captured by $v_{i}$. However, Heckman uses the property of a normally distributed variable to derive the inverse Mills ratio:

$$
E\left(v_{i} \mid v_{i}>-x\right)=\lambda(x)=\frac{\phi(x)}{\Phi(x)} .
$$

Finally, Heckman plugs this $\lambda$ in to get:

$$
Y_{1 i}=X_{i} \beta+p \frac{\phi(X)}{\Phi(X)}+e_{i}=X_{i} \beta+p \lambda_{i}+e_{i}
$$

Thus, researchers can estimate the outcome equation, $Y_{1 i}$ on $X_{i}$, as long as the inverse Mills ratio is also included as a covariate. Estimation of the inverse Mills ratio comes from a regression of the first-stage selection equation, using a probit regression of selection on covariates $\left(Y_{2 i}\right.$ on $\left.Z_{i}\right)$.

Alternatively, newer methods allow for maximum likelihood estimation from maximizing the following likelihood function:

$$
I\left(Y_{2 i}=0\right) P\left(Y_{2 i}=0\right)+I\left(Y_{2 i}=1\right) P\left(Y_{2 i}=1\right) f\left(Y_{1 i} \mid Y_{2 i}=1\right),
$$

where $I\left(Y_{2 i}=0\right)$ and $I\left(Y_{2 i}=1\right)$ are indicators for whether the observation belongs in the control group or the treatment group; $P\left(Y_{2 i}=0\right)$ and $P\left(Y_{2 i}=1\right)$ are the probabilities of these two outcomes occurring; and $f\left(Y_{1 i} \mid Y_{2 i}=1\right)$ is the distribution of the data-generating process conditional on the outcome being observed. In other words, this equation represents the joint likelihood of the data, with indicators for whether or not selection occurred. Thus, the maximum likelihood estimate will result from maximization of this function. ${ }^{2}$

Identification in the Heckman model is from two possible sources: a valid exclusion restriction in the selection equation or data that satisfies the assumption of a normal distribution. One approach is

\footnotetext{
${ }^{1}$ For the Heckman treatment model, the inverse Mills ratio has a slightly different definition for each outcome of the dichotomous selection equation, but the basic idea and estimation technique remain the same.

${ }^{2}$ The general consensus is that MLE performs better than the Heckman two-step method for estimation (Nelson, 1984). Lack of instruments is problematic for any type of estimator. MLE tends to be more efficient, but it also relies on even stronger assumptions than the Heckman two-step method, thus making the use of an instrument even more crucial (Winship \& Mare, 1992).
} 
to have a variable in the selection equation regressors, $Z_{i}$, that is excluded from the first-stage outcome equation regressors, $X_{i}{ }^{3}$ This variable is then an instrument ${ }^{4}$ that needs to affect selection but not the outcome.

When one lacks a valid instrument, ${ }^{5}$ or a variable that affects the selection but not the outcome equation, the inverse Mills ratio is a non-linear function of the exogenous variables in the outcome equation. Therefore the covariance matrix of the error terms is determined solely by the normality assumptions of the model, and estimates are likely to be inaccurate (Angrist \& Krueger, 2001; Hamilton $\&$ Nickerson, 2003). ${ }^{6}$ Thus variables need to be added to the selection equation, which are not present in the outcome equation ${ }^{7}$; this requirement is commonly referred to as "the exclusion restriction." Though the model is technically identified based on the distributional assumptions without such variables, data will rarely fit the distributional assumptions. ${ }^{8}$ In our simulation, we will explore how fragile relying on the assumption of normality can be.

\section{3 | SIMULATION ANALYSIS}

"While the Heckman two-step procedure is appealing, ... its use should not be mechanistic" (Bascle, 2008, p. 292).

Two prior simulation studies have come to different conclusions regarding the use of the Heckman two-step method. Hartman (1991) performs a Monte Carlo analysis comparing alternative methods of accounting for selectivity in treatment groups. The most relevant comparison for our paper is between the Heckman treatment method and a single-stage least squares with a dummy variable for whether the observation was selected (LSDV). Hartman finds that "the standard Heckman correction, which explicitly includes the inverse Mills ratios, is inferior to LSDV, in some cases considerably so" (Hartman, 1991, p. 48). Hartman thus concludes that "LSDV and FIML [Full Information Maximum Likelihood] should be used exclusively for estimation of a selectivity model" (Hartman, 1991, p. 48). In other words, like many critics of the Heckman two-step method (LaLonde, 1986), he suggests that it should not even be considered as a first step in exploratory work.

Newer research has modified Hartman's conclusions, instead attempting to specify tests and rules of thumb to determine when one should use the Heckman method. Stolzenberg and Relles (1997), using simulation, find that they can be $95 \%$ certain that the two-step correction outperforms OLS when "selection bias in the regression coefficient estimate is at least four times the standard error of $\beta_{1}$ ", contradicting "Hartman's (1991) recommendation for wholesale abandonment of the two-step

\footnotetext{
${ }^{3}$ Even with additional variables in the selection equation, collinearity problems are likely: many of the variables in the selection and outcome equations will still be identical (Olsen, 1980; Puhani, 2000).

${ }^{4}$ Note that by instrument here, we refer to a variable that satisfies the exclusion restriction and is relevant in predicting selection. The Heckman selection method is distinct from an instrumental variable approach in that Heckman uses the excluded variable to get an estimate for the inverse Mills ratio which is then plugged into the outcome equation, whereas instrumental variable approaches use the excluded variable to get the exogenous component of an outcome equation regressor and use that in the outcome equation. Thus, "instrument" is simply used to refer to this excluded and relevant variable, rather than to imply use of a traditional instrumental variable method.

${ }^{5}$ See Murray (2006) for an overview of the problem of weak and invalid instruments.

${ }^{6}$ Though normality may occur in some instances, Geary (1947) concludes that "normality is a myth; there never has, and never will be, a normal distribution" (Tukey, 1962, p. 20).

${ }^{7}$ See Leung and Yu (1996) for a review of Monte Carlo studies that show the shortcoming of Heckman's two-step method when this issue causes little variation in the inverse Mills ratio.

${ }^{8}$ See Little (1985).
} 
procedure" (Stolzenberg \& Relles, 1997, p. 503). The authors thus suggest an initial examination of the data to see whether the Heckman two-step method would be appropriate.

We present a simulation model to evaluate the performance of the selection model, under various functional forms and various assumptions about what variables are observed, to guide our recommendations made in the next section for how researchers should approach data that suffers from selection bias. For our simulation, we use Stata to construct the following data:

$$
\begin{aligned}
& Y_{1 i}^{\prime}=X_{2 i}+X_{3 i}+u_{i} \\
& Y_{2 i}^{\prime}=W_{i}+v_{i},
\end{aligned}
$$

where $Y_{1 i}{ }^{\prime}$ and $Y_{2 i}{ }^{\prime}$ are latent variables, with the associated observed variables:

$$
\begin{aligned}
& Y_{1 i}=Y_{1 i}^{\prime}, Y_{2 i}=1 \text { if } Y_{2 i}^{\prime}>t \\
& Y_{1 i} \text { not observed, } Y_{2 i}=0 \text { if } Y_{2 i}^{\prime} \leq t \\
& \text { and } W_{i}=\alpha X_{1 i}+(1-\alpha) X_{2 i} .
\end{aligned}
$$

Thus our data is selected based on a function of $X_{1}$ and $X_{2}$, and the outcome equation is a function of $X_{2}$ and $X_{3}$. We consider that $\mathrm{W}$ is unobservable and $X_{1}$ may or may not be an observable variable that can serve as an instrument for W: it does not affect $Y_{1}$ but does affect selection through W. $X_{2}$ and $X_{3}$ both affect $Y_{1} ; X_{2}$ only affects selection through $\mathrm{W}$. The distribution of the error terms, $u_{i}$ and $v_{i}$, will vary depending on the case analyzed, as several deviations from the assumption of bivariate normality will be considered.

The method of our simulations is to generate the data, perform OLS on the selected data, and compare it with several forms of the Heckman selection method: with selection on observables (i.e., selection equation on $\mathrm{W}$ ); with a valid instrument for the selection on unobservables (i.e., selection equation on $X_{1}$ ); without a valid instrument (i.e., selection equation on $X_{2}$, and dropping $X_{2}$ from the outcome equation); and without an exclusion restriction (i.e., selection equation on $X_{2}$ and $X_{2}$ included in the outcome equation). We consider five distributions of the errors terms and seven estimation methods, where the baseline case will be a bivariate normal distribution. We then consider deviating from this assumption by instead considering two cases with independent errors, and then by considering two cases where errors are jointly, but not normally, distributed. The five distributions are: Case (1): the baseline case of errors distributed according to a bivariate normal distribution; Case (2): errors distributed according to an independent normal distribution; Case (3): errors distributed according to an independent $\chi^{2}$ distribution; Case (4): errors distributed according to a bivariate lognormal distribution; and Case (5): errors distributed according to a bivariate exponential distribution. ${ }^{9}$ We then consider the following estimation methods: OLS, Heckman on observables (with MLE), Heckman with a valid instrument (with MLE), Heckman without an exclusion restriction (with MLE and two-step), and Heckman without a valid instrument (with MLE and twostep). All simulations entailed 10,000 observations, and in each case, the cut-off point, $t$, was chosen such that approximately $25 \%$ of the sample would be selected. Table 1 shows the construction of the data, where we let $\alpha=0.4$ and assume that $X_{1}, X_{2}$, and $X_{3}$ are all correlated with each other. Table 2 shows the regressions of $Y$ on $X_{2}$ and $X_{3}$ before selection occurs, to provide a baseline for our estimates. We see that the coefficients of $X_{2}$ and $X_{3}$ are near 1.00 for each of our models, which is true by construction.

\footnotetext{
${ }^{9}$ We chose to consider the bivariate exponential distribution in addition to the Chi Square distribution because exponential and hyperbolic returns have been found to resemble actual financial data. See Eberlein and Keller (1995). The lognormal distribution is a close variation of the normal distribution, and thus provides a useful comparison.
} 
TABLE 1 Details of Stata results

\begin{tabular}{lllllll} 
& X1 & X2 & X3 & X4 & W & Y \\
X1 & 1.00 & & & & - \\
X2 & 0.40 & 1.00 & & & - \\
X3 & 0.40 & 0.20 & 1.00 & & \\
W & 0.76 & 0.90 & 0.33 & 1.00 & 1.00 \\
Y & 0.43 & 0.65 & 0.65 & 0.67 & - \\
\hline
\end{tabular}

TABLE 2 Initial OLS regressions, before selection

$\begin{array}{lccccc} & \text { (1) OLS } & \text { (2) OLS } & \text { (3) OLS } & \text { (4) OLS } & \text { (5) OLS } \\ & \text { BV norm } & \text { Ind norm } & \text { Ind chi } & \text { BV Lognorm } & \text { BV Exp } \\ \text { X2 } & 1.00 & 1.01 & 1.02 & 1.02 & 0.99 \\ \text { X3 } & (0.01) & (0.01) & (0.01) & (0.01) & (0.01) \\ & 0.99 & 0.99 & 0.97 & 0.98 & 1.00 \\ \text { Constant } & (0.01) & (0.01) & (0.01) & (0.01) & (0.01) \\ & -0.00 & 0.01 & 1.01 & 0.32 & 0.50 \\ \text { Selection } & (0.01) & (0.01) & (0.01) & (0.01) & (0.01) \\ \text { W } & & & & 0.35 & 0.31 \\ & 0.24 & 0.24 & 0.19 & (0.00) & (0.00) \\ \text { Constant } & (0.00) & (0.00) & (0.00) & 0.28 & (0.00) \\ & 0.25 & 0.24 & 0.25 & (0.00) & 0.25\end{array}$

Note: SEs are listed below coefficients, in parentheses.

Table 3 shows the results of the first model with $25.09 \%$ of the sample selected, where the errors are distributed according to a bivariate normal distribution, as modeled in the Heckman method. Column 1 shows that OLS is biased on the selected subsample, with the coefficient of $X_{2}$ being meaningfully different from 1 , at 0.81 . Note that we expect the coefficient of $X_{2}$ to be that which suffers bias as selection occurs on $\mathrm{W}$, which is a function of $X_{2}$. We then see that using MLE on the Heckman model reduces the bias on the coefficient on $X_{2}$ if we can control for the selection variable $\mathrm{W}$ in Column 2, if we can use $X_{1}$ as an instrument for $\mathrm{W}$ in the selection equation in Column 3, or if we simply use the same variables in the selection and outcome equations with MLE or two-step in Columns 4 or $5 .{ }^{10}$ Without an exclusion restriction, the true value of the coefficient is still within one standard error of the estimated value, but the estimated parameter is farther from 1.00 and the standard errors are inflated compared to when a valid instrument is used. Finally, in Columns 6 and 7, we see that using $X_{2}$ as an (invalid) instrument in the selection equation moderately affects the coefficient of $X_{3}$, and in fact performs worse than OLS. Thus, our simulation confirms that if the errors are distributed via a bivariate normal distribution, than the Heckman method outperforms OLS even without an exclusion restriction.

Table 4 shows the results of Model 2 with $24.04 \%$ of the sample selected; the errors are normally, but independently, distributed. Column 1 shows that OLS is actually not biased on the selected subsample. Even so, we find that the Heckman method performs as well as OLS if we control for the selection variable $\mathrm{W}$ and if we can use $X_{1}$ as an instrument for $\mathrm{W}$ in the selection equation, as seen in

\footnotetext{
${ }^{10}$ Recall that with no exclusion restriction, the Heckman method still corrects the estimate here because we have assumed bivariate normality of the errors.
} 
TABLE 3 Bivariate normal errors (25.09\% selected)

\begin{tabular}{|c|c|c|c|c|c|c|c|}
\hline & (1) OLS & $\begin{array}{l}\text { (2) Observables } \\
\text { MLE }\end{array}$ & $\begin{array}{l}\text { (3) Valid Inst. } \\
\text { MLE }\end{array}$ & $\begin{array}{l}\text { (4) No Excl. } \\
\text { MLE }\end{array}$ & $\begin{array}{l}\text { (5) No Excl. } \\
\text { Two-step }\end{array}$ & $\begin{array}{l}\text { (6) Bad Inst. } \\
\text { MLE }\end{array}$ & $\begin{array}{l}\text { (7) Bad Inst. } \\
\text { Two-step }\end{array}$ \\
\hline \multicolumn{8}{|l|}{ Main } \\
\hline \multirow[t]{2}{*}{$\mathrm{X} 2$} & 0.809 & 1.051 & 1.051 & 0.948 & 0.939 & & \\
\hline & $(0.0216)$ & $(0.0357)$ & $(0.0357)$ & $(0.125)$ & $(0.171)$ & & \\
\hline \multirow[t]{2}{*}{$\mathrm{X} 3$} & 0.973 & 1.025 & 1.025 & 1.002 & 1.000 & 0.870 & 0.814 \\
\hline & $(0.0190)$ & $(0.0206)$ & $(0.0206)$ & $(0.0318)$ & $(0.0393)$ & $(0.0249)$ & $(0.0286)$ \\
\hline \multirow[t]{2}{*}{ Constant } & 0.631 & -0.116 & -0.116 & 0.203 & 0.230 & 2.532 & 3.076 \\
\hline & $(0.0245)$ & $(0.0890)$ & $(0.0890)$ & $(0.377)$ & $(0.520)$ & $(0.0457)$ & $(0.0815)$ \\
\hline \multicolumn{8}{|l|}{ Select } \\
\hline \multirow[t]{2}{*}{ w } & & 0.997 & & & & & \\
\hline & & $(0.0455)$ & & & & & \\
\hline \multirow[t]{2}{*}{$\mathrm{X} 2$} & & -0.0226 & 0.576 & 0.670 & 0.670 & 0.715 & 0.670 \\
\hline & & $(0.0353)$ & $(0.0183)$ & $(0.0176)$ & $(0.0176)$ & $(0.0162)$ & $(0.0176)$ \\
\hline \multirow[t]{2}{*}{$\mathrm{X} 3$} & & 0.00750 & 0.00750 & 0.136 & 0.137 & 0.119 & 0.137 \\
\hline & & $(0.0166)$ & $(0.0166)$ & $(0.0153)$ & $(0.0153)$ & $(0.0151)$ & $(0.0153)$ \\
\hline \multirow[t]{2}{*}{$\mathrm{X} 1$} & & & 0.399 & & & & \\
\hline & & & $(0.0182)$ & & & & \\
\hline \multirow[t]{2}{*}{ Constant } & & -0.871 & -0.871 & -0.823 & -0.823 & -0.857 & -0.823 \\
\hline & & $(0.0168)$ & $(0.0168)$ & $(0.0160)$ & $(0.0160)$ & $(0.0158)$ & $(0.0160)$ \\
\hline \multirow[t]{2}{*}{ Lambda } & & & & & 0.289 & & -1.756 \\
\hline & & & & & $(0.375)$ & & $(0.0656)$ \\
\hline
\end{tabular}

Note: SEs are listed below coefficients, in parentheses.

Columns 2 and 3. But when we lack an exclusion restriction, and estimation thus relies on distributional assumptions, which are not satisfied here because the errors are not bivariate normal, the Heckman model performs worse than OLS, especially in Column 5 when the two-step method is employed. The bias is worsened when an invalid instrument is used in Column 6, and is again especially problematic with the two-step method in Column 7.

Similar results apply to Models 3 and 5 in Tables 5 and 7, when the errors are distributed according to an independent $\chi^{2}$ distribution and a bivariate exponential distribution. In particular, Column 1 shows that OLS is biased on the selected subsample, and the Heckman method out-performs OLS if we can control for the selection variable $\mathrm{W}$ and if we can use $X_{1}$ as an instrument for $\mathrm{W}$ in the selection equation, as seen in Columns 2 and 3. But when we lack an exclusion restriction in model 5 , the Heckman model performs worse than OLS and the bias is worsened when an invalid instrument is used in models 6 and 7.

In Table 6, when the errors are distributed according to a bivariate lognormal, we find that that the Heckman method performs better than OLS even with no exclusion restriction, and only performs worse when an invalid instrument is used. Perhaps due to the close relationship between the bivariate lognormal and bivariate normal distributions, we find that this variation from the assumption of bivariate normality is not problematic.

Overall we find that, with a valid instrument or selection on observables, the Heckman method generally performs comparably or significantly better than OLS, regardless of the distribution of the error terms. However, the comparison between OLS and the Heckman method with no exclusion restriction depends on the distribution of the error terms. In particular, with no exclusion restriction, 
TABLE 4 Independent normal errors (24.04\% selected)

\begin{tabular}{|c|c|c|c|c|c|c|c|}
\hline & (1) OLS & $\begin{array}{l}\text { (2) Observables } \\
\text { MLE }\end{array}$ & $\begin{array}{l}\text { (3) Valid Inst. } \\
\text { MLE }\end{array}$ & $\begin{array}{l}\text { (4) No Excl. } \\
\text { MLE }\end{array}$ & $\begin{array}{l}\text { (5) No Excl. } \\
\text { Two-step }\end{array}$ & $\begin{array}{l}\text { (6) Bad Inst. } \\
\text { MLE }\end{array}$ & $\begin{array}{l}\text { (7) Bad Inst. } \\
\text { Two-step }\end{array}$ \\
\hline \multicolumn{8}{|l|}{ Main } \\
\hline \multirow[t]{2}{*}{$\mathrm{X} 2$} & 1.009 & 1.014 & 1.014 & 1.110 & 1.185 & & \\
\hline & $(0.0235)$ & $(0.0475)$ & $(0.0475)$ & $(0.129)$ & $(0.171)$ & & \\
\hline \multirow[t]{2}{*}{$\mathrm{X} 3$} & 1.035 & 1.036 & 1.036 & 1.055 & 1.071 & 0.922 & 0.837 \\
\hline & $(0.0205)$ & $(0.0220)$ & $(0.0220)$ & $(0.0331)$ & $(0.0403)$ & $(0.0281)$ & $(0.0346)$ \\
\hline \multirow[t]{2}{*}{ Constant } & 0.0342 & 0.0183 & 0.0183 & -0.267 & -0.490 & 2.284 & 2.986 \\
\hline & $(0.0271)$ & $(0.126)$ & $(0.126)$ & $(0.379)$ & $(0.505)$ & $(0.0485)$ & $(0.0939)$ \\
\hline \multicolumn{8}{|c|}{ Select_indnorm } \\
\hline \multirow[t]{2}{*}{ w } & & 0.985 & & & & & \\
\hline & & $(0.0477)$ & & & & & \\
\hline \multirow[t]{2}{*}{$\mathrm{X} 2$} & & 0.0320 & 0.623 & 0.716 & 0.715 & 0.770 & 0.715 \\
\hline & & $(0.0371)$ & $(0.0191)$ & $(0.0183)$ & $(0.0183)$ & $(0.0167)$ & $(0.0183)$ \\
\hline \multirow[t]{2}{*}{$\mathrm{X} 3$} & & 0.0234 & 0.0234 & 0.145 & 0.145 & 0.124 & 0.145 \\
\hline & & $(0.0171)$ & $(0.0171)$ & $(0.0157)$ & $(0.0157)$ & $(0.0155)$ & $(0.0157)$ \\
\hline \multirow[t]{2}{*}{$\mathrm{X} 1$} & & & 0.394 & & & & \\
\hline & & & $(0.0191)$ & & & & \\
\hline \multirow[t]{2}{*}{ Constant } & & -0.932 & -0.932 & -0.882 & -0.882 & -0.928 & -0.882 \\
\hline & & $(0.0174)$ & $(0.0174)$ & $(0.0165)$ & $(0.0165)$ & $(0.0163)$ & $(0.0165)$ \\
\hline \multirow[t]{2}{*}{ Lambda } & & & & & 0.366 & & -2.053 \\
\hline & & & & & $(0.352)$ & & $(0.0743)$ \\
\hline
\end{tabular}

Note: SEs are listed below coefficients, in parentheses.

MLE generally performs significantly better than the two-step estimation method, confirming prior research (Nelson, 1984). In addition, except for when errors are distributed according to a bivariate normal or bivariate lognormal distribution, the Heckman method with no exclusion restriction performs significantly worse than OLS. As indicated earlier, data rarely will be distributed exactly according to a normal distribution. Thus our simulation analysis indicates that extreme care is warranted when using the Heckman method with real-world data and without an exclusion restriction, given that distributions may not be normal.

\section{1 | Coping with sample selection}

The importance of the exclusion restriction, as illustrated by the simulation analysis, is challenging for researchers because instruments are hard to find. Thus, we encourage not only the search for instruments but also acceptance and use of other techniques for the many cases in which a valid instrument will not be available. Figure 1 provides a set of steps that can be used by researchers to guide a clearer presentation of empirical research that suffers from selection bias. There are a few empirical papers that provide excellent examples of how to approach selection issues, roughly consistent with our Figure 1 approach. Chang, Kogut, and Yang (2016) stands out in how the authors approach the issue of self-selection and provide a sound logic for the exclusion restriction being met. The paper includes a clear description of the context of the selection issue and the appropriateness of their instruments, as well as presentation of both the first and second stage results. 
TABLE 5 Independent $\chi^{2}$ errors $(25.36 \%$ selected $)$

\begin{tabular}{|c|c|c|c|c|c|c|}
\hline & (1) OLS & $\begin{array}{l}\text { (2) Observables } \\
\text { MLE }\end{array}$ & $\begin{array}{l}\text { (3) Valid Inst. } \\
\text { MLE }\end{array}$ & $\begin{array}{l}\text { (5) No Excl. } \\
\text { Two-step }\end{array}$ & $\begin{array}{l}\text { (6) Bad Inst. } \\
\text { MLE }\end{array}$ & $\begin{array}{l}\text { (7) Bad Inst. } \\
\text { Two-step }\end{array}$ \\
\hline \multicolumn{7}{|l|}{ Main } \\
\hline $\mathrm{X} 2$ & $\begin{array}{c}1.052 \\
(0.0306)\end{array}$ & $\begin{array}{c}1.030 \\
(0.0638)\end{array}$ & $\begin{array}{c}1.030 \\
(0.0638)\end{array}$ & $\begin{array}{c}1.086 \\
(0.338)\end{array}$ & & \\
\hline $\mathrm{X} 3$ & $\begin{array}{c}0.995 \\
(0.0310)\end{array}$ & $\begin{array}{c}0.990 \\
(0.0334)\end{array}$ & $\begin{array}{c}0.990 \\
(0.0334)\end{array}$ & $\begin{array}{c}1.002 \\
(0.0824)\end{array}$ & $\begin{array}{c}0.982 \\
(0.0390)\end{array}$ & $\begin{array}{c}0.760 \\
(0.0495)\end{array}$ \\
\hline Constant & $\begin{array}{c}1.011 \\
(0.0350)\end{array}$ & $\begin{array}{c}1.092 \\
(0.213)\end{array}$ & $\begin{array}{c}1.092 \\
(0.213)\end{array}$ & $\begin{array}{c}0.879 \\
(1.324)\end{array}$ & $\begin{array}{c}3.269 \\
(0.0751)\end{array}$ & $\begin{array}{l}5.111 \\
(0.173)\end{array}$ \\
\hline Select_ind & & & & & & \\
\hline w & & $\begin{array}{c}0.662 \\
(0.0429)\end{array}$ & & & & \\
\hline $\mathrm{X} 2$ & & $\begin{array}{l}0.0000382 \\
(0.0343)\end{array}$ & $\begin{array}{c}0.397 \\
(0.0165)\end{array}$ & $\begin{array}{c}0.476 \\
(0.0157)\end{array}$ & $\begin{array}{l}0.561 \\
(0.0146)\end{array}$ & $\begin{array}{c}0.476 \\
(0.0157)\end{array}$ \\
\hline $\mathrm{X} 3$ & & $\begin{array}{c}0.0210 \\
(0.0158)\end{array}$ & $\begin{array}{c}0.0210 \\
(0.0158)\end{array}$ & $\begin{array}{c}0.108 \\
(0.0146)\end{array}$ & $\begin{array}{c}0.0901 \\
(0.0147)\end{array}$ & $\begin{array}{c}0.108 \\
(0.0146)\end{array}$ \\
\hline $\mathrm{X} 1$ & & & $\begin{array}{c}0.265 \\
(0.0172)\end{array}$ & & & \\
\hline Constant & & $\begin{array}{l}-0.755 \\
(0.0149)\end{array}$ & $\begin{array}{l}-0.755 \\
(0.0149)\end{array}$ & $\begin{array}{l}-0.740 \\
(0.0147)\end{array}$ & $\begin{array}{l}-0.780 \\
(0.0148)\end{array}$ & $\begin{array}{l}-0.740 \\
(0.0147)\end{array}$ \\
\hline Lambda & & & & $\begin{array}{r}0.0997 \\
(0.993)\end{array}$ & & $\begin{array}{r}-3.071 \\
(0.136)\end{array}$ \\
\hline
\end{tabular}

Notes: Model (4) omitted due to failure of MLE to converge. SEs are listed below coefficients, in parentheses.

In terms of the application of Figure 1, the following scenarios arise. First, when managers contending with the early stages of a phenomenon are making decisions under high uncertainty, selecting between equally plausible choices may be viewed as sufficiently exogenous for a reduced-form ordinary least squares model. We ought to accept that such situations exist and continue to allow researchers to study them. In Figure 1, this would be the "Ordinary Least Squares" branch after either type of selection. Following the use of this method, the researcher would then "Discuss issues with unobserved selection, expected direction". In this case, the expected bias would be zero due to the amount of uncertainty faced by the manager. Second, there are situations when other methods can be justified on the basis of economic arguments and theory. For example, propensity-score matching may handle the endogeneity problem sufficiently from a theoretical standpoint if the case can be made that the differences are observable. ${ }^{11}$ As in step four of Figure 1, following the use of this method, the authors should then discuss any possible unobserved causes of selection, or argue that selection is observable, providing specifics from the context. Finally, in some cases, discussion of plausible types of unobserved heterogeneity and their possible impact on negating results based on correlation should be preferred. In fact, given the consequences of misapplication of the technique discussed above, discussion based on economic theory of the phenomena is generally preferred to a "robustness" check performed by incorrectly using the Heckman two-step method without justification. Thus, in Figure 1, we develop a decision structure to guide researchers, with these scenarios in mind. ${ }^{12}$

\footnotetext{
${ }^{11}$ For example, Hamilton and Nickerson (2003).

${ }^{12}$ Larcker and Rusticus (2010) also provide a useful set of instructions for how to approach endogeneity in a paper analyzing empirical estimation methods in the Accounting literature.
} 
TABLE 6 Bivariate lognormal errors (24.89\% selected)

\begin{tabular}{|c|c|c|c|c|c|c|}
\hline & (1) OLS & $\begin{array}{l}\text { (2) Observables } \\
\text { Two-step' }\end{array}$ & $\begin{array}{l}\text { (3) Valid Inst. } \\
\text { Two-step' }\end{array}$ & $\begin{array}{l}\text { (5) No Excl. } \\
\text { Two-step }\end{array}$ & $\begin{array}{l}\text { (6) Bad Inst. } \\
\text { MLE }\end{array}$ & $\begin{array}{l}\text { (7) Bad Inst. } \\
\text { Two-step }\end{array}$ \\
\hline \multicolumn{7}{|l|}{ Main } \\
\hline \multirow[t]{2}{*}{$\mathrm{X} 2$} & 0.776 & 1.031 & 1.031 & 1.097 & & \\
\hline & $(0.0409)$ & $(0.0560)$ & $(0.0560)$ & $(0.109)$ & & \\
\hline \multirow[t]{2}{*}{$\mathrm{X} 3$} & 0.922 & 0.975 & 0.975 & 0.984 & 0.864 & 0.808 \\
\hline & $(0.0302)$ & $(0.0311)$ & $(0.0311)$ & $(0.0359)$ & $(0.0326)$ & $(0.0327)$ \\
\hline \multirow[t]{2}{*}{ Constant } & 0.741 & 0.254 & 0.254 & 0.0952 & 1.903 & 2.159 \\
\hline & $(0.0545)$ & $(0.0912)$ & $(0.0912)$ & $(0.210)$ & $(0.0426)$ & $(0.0507)$ \\
\hline \multicolumn{7}{|c|}{ Select_log } \\
\hline \multirow[t]{2}{*}{ w } & & 2.643 & & & & \\
\hline & & $(0.0776)$ & & & & \\
\hline \multirow[t]{2}{*}{$\mathrm{X} 2$} & & 0.0417 & 1.628 & 1.526 & 1.524 & 1.526 \\
\hline & & $(0.0503)$ & $(0.0359)$ & $(0.0304)$ & $(0.0302)$ & $(0.0304)$ \\
\hline \multirow[t]{2}{*}{$\mathrm{X} 3$} & & 0.0103 & 0.0103 & 0.287 & 0.279 & 0.287 \\
\hline & & $(0.0234)$ & $(0.0234)$ & $(0.0192)$ & $(0.0192)$ & $(0.0192)$ \\
\hline \multirow[t]{2}{*}{$\mathrm{X} 1$} & & & 1.057 & & & \\
\hline & & & $(0.0311)$ & & & \\
\hline \multirow[t]{2}{*}{ Constant } & & -1.616 & -1.616 & -1.256 & -1.268 & -1.256 \\
\hline & & $(0.0315)$ & $(0.0315)$ & $(0.0241)$ & $(0.0240)$ & $(0.0241)$ \\
\hline \multirow[t]{2}{*}{ Lambda } & & 0.408 & 0.408 & 0.421 & & -0.812 \\
\hline & & $(0.0607)$ & $(0.0607)$ & $(0.131)$ & & $(0.0507)$ \\
\hline
\end{tabular}

Notes: Model (4) omitted due to failure of MLE to converge.' indicates use of two-step method in place of MLE due to failure of MLE to converge. SEs are listed below coefficients, in parentheses.

Consistent with the above discussion, the theme throughout the figure is that the researcher needs to use economic arguments from their understanding of the context to motivate which methods they use, and how they discuss their results. This knowledge should also guide their search for valid exclusion restrictions. We illustrate this approach in our empirical analysis in Section 5.

\section{4 | META-ANALYSIS}

"The field of strategic management is fundamentally predicated on the idea that management's decisions are endogenous to their expected performance outcomes." (Hamilton \& Nickerson, 2003, p. 51)

\section{1 | Meta-analysis of the strategy and organizational theory literatures}

This section examines papers in strategy and organizational theory, published between 1995 and 2016, which use the Heckman two-step method; our aim is to determine whether they address the issues discussed above. Specifically, we examine trends over time and across journals to pinpoint whether the field has responded to calls, including that of Hamilton and Nickerson (2003), to employ Heckman with valid instruments. We examine papers published in Strategic Management Journal (SMJ), Management Science (MS), Organization Science (OrgSci), and Administrative Science Quarterly (ASQ) that cite Heckman (1979). Using the Web of Science Social Science Citation 
TABLE 7 Bivariate exponential errors (24.89\% selected)

\begin{tabular}{|c|c|c|c|c|c|c|c|}
\hline & (1) OLS & $\begin{array}{l}\text { (2) Observables } \\
\text { MLE }\end{array}$ & $\begin{array}{l}\text { (3) Valid Inst. } \\
\text { MLE }\end{array}$ & $\begin{array}{l}\text { (4) No Excl. } \\
\text { MLE }\end{array}$ & $\begin{array}{l}\text { (5) No Excl. } \\
\text { Two-step }\end{array}$ & $\begin{array}{l}\text { (6) Bad Inst. } \\
\text { MLE }\end{array}$ & $\begin{array}{l}\text { (7) Bad Inst. } \\
\text { Two-step }\end{array}$ \\
\hline \multicolumn{8}{|l|}{ Main } \\
\hline $\mathrm{X} 2$ & $\begin{array}{l}0.869 \\
(0.0143)\end{array}$ & $\begin{array}{l}1.010 \\
(0.0228)\end{array}$ & $\begin{array}{l}1.010 \\
(0.0228)\end{array}$ & $\begin{array}{c}0.935 \\
(0.100)\end{array}$ & $\begin{array}{l}0.880 \\
(0.0611)\end{array}$ & & \\
\hline $\mathrm{X} 3$ & $\begin{array}{l}0.982 \\
(0.0114)\end{array}$ & $\begin{array}{l}1.012 \\
(0.0121)\end{array}$ & $\begin{array}{l}1.012 \\
(0.0121)\end{array}$ & $\begin{array}{l}0.995 \\
(0.0221)\end{array}$ & $\begin{array}{c}0.984 \\
(0.0160)\end{array}$ & $\begin{array}{c}0.884 \\
(0.0169)\end{array}$ & $\begin{array}{c}0.830 \\
(0.0228)\end{array}$ \\
\hline Constant & $\begin{array}{l}0.758 \\
(0.0177)\end{array}$ & $\begin{array}{l}0.425 \\
(0.0448)\end{array}$ & $\begin{array}{l}0.425 \\
(0.0448)\end{array}$ & $\begin{array}{c}0.604 \\
(0.235)\end{array}$ & $\begin{array}{c}0.733 \\
(0.141)\end{array}$ & $\begin{array}{c}2.322 \\
(0.0233)\end{array}$ & $\begin{array}{c}2.737 \\
(0.0473)\end{array}$ \\
\hline Select_exp & & & & & & & \\
\hline w & & $\begin{array}{c}1.728 \\
(0.0579)\end{array}$ & & & & & \\
\hline $\mathrm{X} 2$ & & $\begin{array}{l}-0.0220 \\
(0.0410)\end{array}$ & $\begin{array}{l}1.015 \\
(0.0248)\end{array}$ & $\begin{array}{c}1.072 \\
(0.0231)\end{array}$ & $\begin{array}{c}1.073 \\
(0.0230)\end{array}$ & $\begin{array}{c}1.128 \\
(0.0206)\end{array}$ & $\begin{array}{c}1.073 \\
(0.0230)\end{array}$ \\
\hline $\mathrm{X} 3$ & & $\begin{array}{l}0.00259 \\
(0.0192)\end{array}$ & $\begin{array}{l}0.00259 \\
(0.0192)\end{array}$ & $\begin{array}{l}0.202 \\
(0.0170)\end{array}$ & $\begin{array}{l}0.202 \\
(0.0170)\end{array}$ & $\begin{array}{l}0.170 \\
(0.0166)\end{array}$ & $\begin{array}{l}0.202 \\
(0.0170)\end{array}$ \\
\hline $\mathrm{X} 1$ & & & $\begin{array}{c}0.691 \\
(0.0232)\end{array}$ & & & & \\
\hline Constant & & $\begin{array}{l}-1.172 \\
(0.0228)\end{array}$ & $\begin{array}{l}-1.172 \\
(0.0228)\end{array}$ & $\begin{array}{l}-1.009 \\
(0.0194)\end{array}$ & $\begin{array}{l}-1.009 \\
(0.0194)\end{array}$ & $\begin{array}{l}-1.095 \\
(0.0188)\end{array}$ & $\begin{array}{l}-1.009 \\
(0.0194)\end{array}$ \\
\hline Lambda & & & & & $\begin{array}{c}0.0173 \\
(0.0957)\end{array}$ & & $\begin{array}{l}-1.324 \\
(0.0401)\end{array}$ \\
\hline
\end{tabular}

Note: SEs are listed below coefficients, in parentheses.

Network, we identified 165 articles published between 1995 and 2016 that employed the Heckman two-step method. The years 1995 and 1996 returned no such citations and thus are not included in the tables.

Table 8 presents the papers by year and journal in Columns 1 and 2. Column 3 reports whether papers use the Heckman truncation/selection or treatment model. Column 4 specifies the general method used to estimate the Heckman model: MLE or two-step estimation. Columns 5 and 6 indicate whether the Heckman two-step method is reported in a table or appendix, or is discussed solely in passing. Many articles in the latter categories use Heckman solely as a robustness check; though Heckman is not central to the empirics of these papers, we include them in our analysis for completeness.

Columns 7 and 8 classify papers by whether or not they appear to use Heckman correctly. "Exclusion restriction" is coded yes if a variable in the selection equation does not appear in the outcome equation, and no if the same variables are used in both equations. Exclusion restriction is coded as unclear if the first stage is neither shown nor explicitly described. Then, we determine whether papers claim to have a valid instrument. "Instrument Claim" is coded as yes if the paper explicitly discusses and explains the variable used as an instrument. Because this characterization can be subjective, we focus our discussion on the existence of an exclusion restriction. Finally, Columns 9 and 10 look at the methods employed in the first and second stages of analysis. 
The Heckman Method should only be used in cases of selection, where firms do not randomly decide to take the strategic action being examined. For cases of simultaneity, omitted variables bias, and other sources of endogeneity, it is not appropriate.

Thus, this step involves researching the context and decision in question to understand the type of

endogeneity present.
Once the data is acquired, the researcher can determine the type of selection problem faced. If the researcher only has outcome data on the "treated" firms, then this is a truncation model. If the researcher has outcome data on both "treated" and "untreated" firms, then it is a selection model. The alternatives available in the next step will differ slightly based on the type of selection.

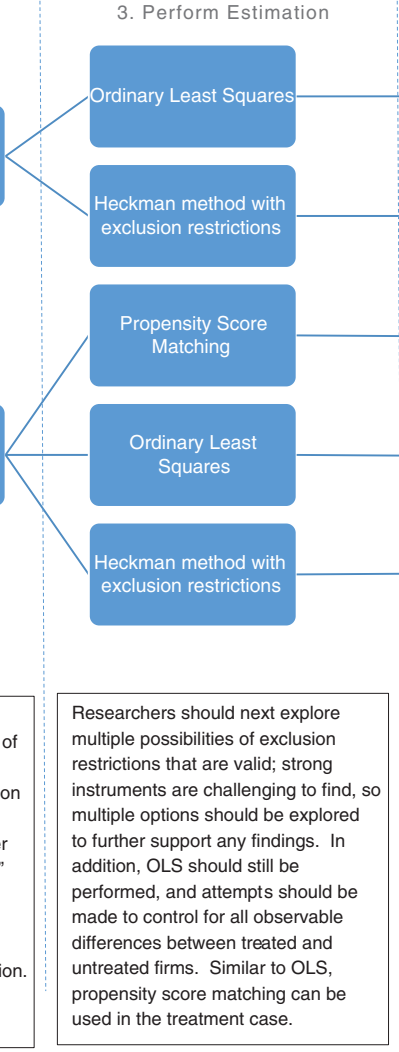

4.Present/Discuss Results

Discuss issues with unobserved selection, expected direction

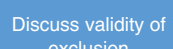
exclusion

Discuss issues with unobserved selection, expected direction

Discuss issues with unobserved selection, expected direction

Discuss validity of exclusion
Finally, and perhaps most importantly, researchers should discuss and present the results clearly. Economic arguments should be made for why an exclusion restriction is valid. If OLS or Propensity Square Matching is used, the researcher should discuss the expected direction of the bias using their understanding of the context and data. If these approaches provide a consistent qualitative conclusion, the researcher has a strong result.

FIGURE 1 Researcher endogeneity decision tree

Table 9 presents the number of citations per year and the percentage that have an exclusion restriction. Of the 165 papers, 47 cases are unclear regarding whether an exclusion restriction is employed; 92 clearly use an exclusion restriction and 26 do not. In Table 10, we see that each journal has a significant number of citations. Table 10 shows that papers in Management Science (MS) perform slightly better than the other journals in terms of discussing the validity of the instrument: $50 \%$ of its articles claim to have a valid instrument, compared to under $40 \%$ in each of the other journals.

Between 1995 and publication of Hamilton and Nickerson (2003), an average of 2.44 papers per year cited Heckman (1979). Between 2004 and 2016, this number grew to an average of 10.92 papers per year. Thus, use of the Heckman two-step method increased markedly. Furthermore, 39\% of papers in the early period have an exclusion restriction, compared to $58 \%$ in the later period. Since use of the Heckman method has proliferated, the field needs to heed advice on how to deal with endogeneity in order to accurately employ advanced methodological techniques. Though increased use of an exclusion restriction is an improvement, the exclusion restriction is necessary but not sufficient for correct application of the Heckman two-step method.

Use of an exclusion restriction is a lenient measure. Exclusion restrictions are only effective if valid instruments are employed. Heckman still appears to be employed mechanistically: few papers justify the use of an instrument on the basis of economic reasoning; only 54 of the 165 papers claim to have a valid instrument. Furthermore, the criteria typically employed in economics journals for the validity of an instrument are both economic intuition and objective statistical tests. Under these 
TABLE 8 Strategy papers citing Heckman (1979)

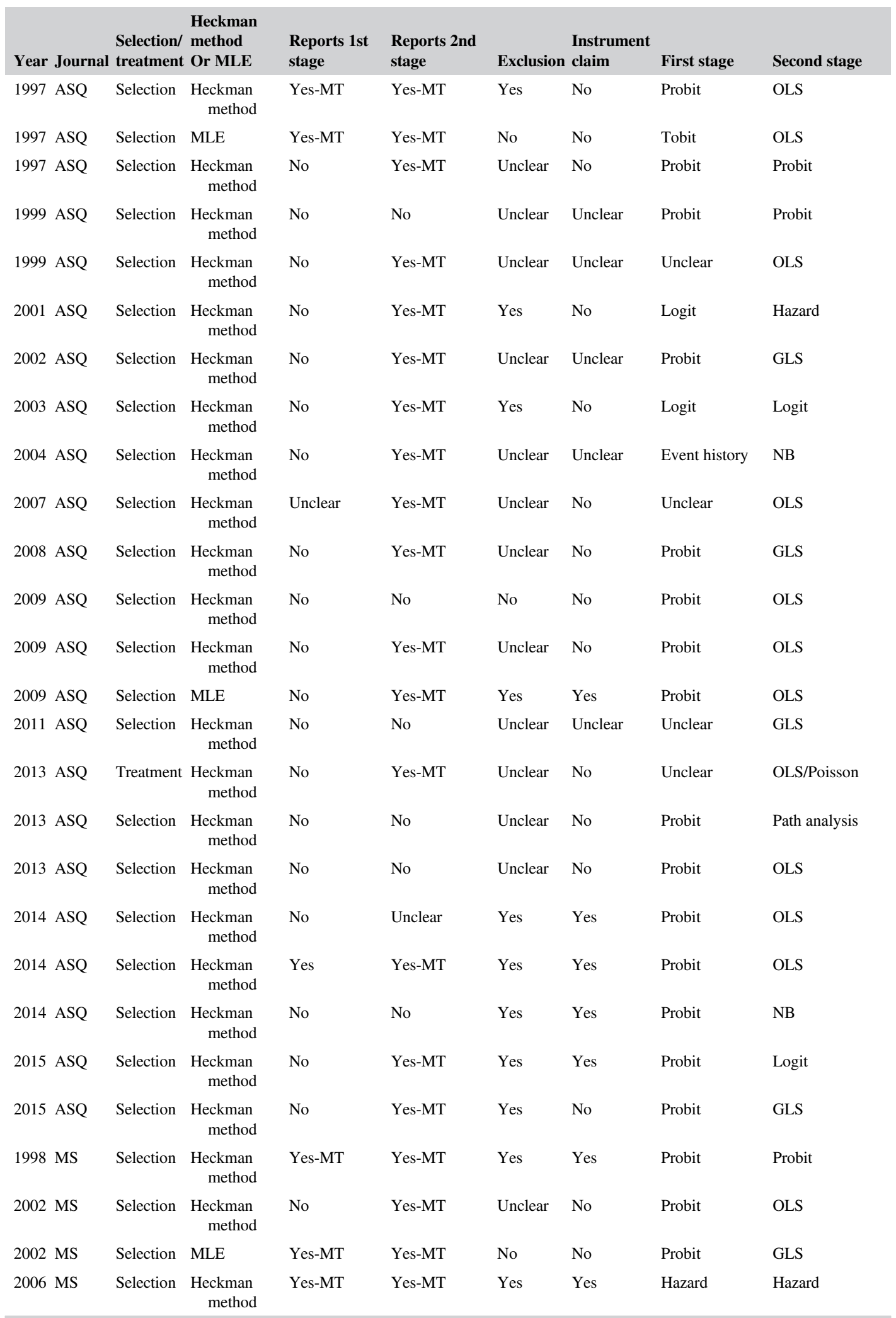


TABLE 8 (Continued)

\begin{tabular}{|c|c|c|c|c|c|c|c|c|c|}
\hline Year & Journal & $\begin{array}{l}\text { Selection/ } \\
\text { treatment }\end{array}$ & $\begin{array}{l}\text { Heckman } \\
\text { method } \\
\text { Or MLE }\end{array}$ & $\begin{array}{l}\text { Reports 1st } \\
\text { stage }\end{array}$ & $\begin{array}{l}\text { Reports 2nd } \\
\text { stage }\end{array}$ & Exclusion & $\begin{array}{l}\text { Instrument } \\
\text { claim }\end{array}$ & First stage & Second stage \\
\hline 2006 & MS & Selection & $\begin{array}{l}\text { Heckman } \\
\text { method }\end{array}$ & No & No & Yes & Yes & Probit & Probit \\
\hline 2006 & MS & Selection & $\begin{array}{l}\text { Heckman } \\
\text { method }\end{array}$ & Yes-MT & Yes-MT & Yes & Yes & Probit & OLS \\
\hline 2008 & MS & Selection & $\begin{array}{l}\text { Heckman } \\
\text { method }\end{array}$ & No & Yes-MT & Unclear & Unclear & Probit & NB \\
\hline 2009 & MS & Selection & $\begin{array}{l}\text { Heckman } \\
\text { method }\end{array}$ & No & Yes-MT & Unclear & No & Probit & OLS \\
\hline 2009 & MS & Selection & $\begin{array}{l}\text { Heckman } \\
\text { method }\end{array}$ & No & No & Yes & Yes & Probit & Probit \\
\hline 2009 & MS & Selection & $\begin{array}{l}\text { Heckman } \\
\text { method }\end{array}$ & No & Yes-MT & Yes & Yes & Probit & OLS \\
\hline 2010 & MS & Unclear & $\begin{array}{l}\text { Heckman } \\
\text { method }\end{array}$ & No & No & Unclear & No & Unclear & Unclear \\
\hline 2011 & MS & Selection & $\begin{array}{l}\text { Heckman } \\
\text { method }\end{array}$ & Yes & Yes-MT & Yes & Yes & Probit & OLS \\
\hline 2012 & MS & Treatment & $\begin{array}{l}\text { Heckman } \\
\text { method }\end{array}$ & Yes-MT & Yes-MT & No & No & Probit & OLS \\
\hline 2012 & MS & Selection & $\begin{array}{l}\text { Heckman } \\
\text { method }\end{array}$ & Unclear & Unclear & Unclear & Yes & Unclear & Unclear \\
\hline 2012 & MS & Selection & $\begin{array}{l}\text { Heckman } \\
\text { method }\end{array}$ & No & No & Yes & No & Probit & OLS \\
\hline 2013 & MS & Selection & $\begin{array}{l}\text { Heckman } \\
\text { method }\end{array}$ & Yes & Yes-MT & Yes & Yes & Probit & OLS \\
\hline 2013 & MS & Selection & $\begin{array}{l}\text { Heckman } \\
\text { method }\end{array}$ & No & Yes-MT & Yes & Yes & Probit & OLS \\
\hline 2015 & MS & Selection & $\begin{array}{l}\text { Heckman } \\
\text { method }\end{array}$ & Yes-AP & Yes-AP & Yes & Yes & Probit & OLS \\
\hline 2015 & MS & Selection & $\begin{array}{l}\text { Heckman } \\
\text { method }\end{array}$ & Yes & Yes-MT & Yes & No & Probit & ANCOVA \\
\hline 2015 & MS & Selection & $\begin{array}{l}\text { Heckman } \\
\text { method }\end{array}$ & Yes & Yes-MT & Yes & No & Probit & Probit \\
\hline 2015 & MS & Selection & $\begin{array}{l}\text { Heckman } \\
\text { method }\end{array}$ & Yes & Yes-MT & Yes & No & Probit & OLS \\
\hline 2016 & MS & Selection & $\begin{array}{l}\text { Heckman } \\
\text { method }\end{array}$ & No & No & No & No & Unclear & $\mathrm{FE}$ \\
\hline 2016 & MS & Selection & $\begin{array}{l}\text { Heckman } \\
\text { method }\end{array}$ & Yes-Appendix & Yes-MT & Yes & No & Probit & OLS \\
\hline 2016 & MS & Selection & $\begin{array}{l}\text { Heckman } \\
\text { method }\end{array}$ & Yes-Appendix & Yes-Appendix & Yes & Yes & Probit & OLS \\
\hline 2001 & OrgSci & Selection & $\begin{array}{l}\text { Heckman } \\
\text { method }\end{array}$ & No & Yes-MT & Yes & No & Probt & OLS \\
\hline 2003 & OrgSci & Selection & $\begin{array}{l}\text { Heckman } \\
\text { method }\end{array}$ & Yes-MT & Yes-AP & No & No & Logit & Logit \\
\hline 2003 & OrgSci & Selection & $\begin{array}{l}\text { Heckman } \\
\text { method }\end{array}$ & Yes-MT & Yes-MT & Yes & Unclear & Probit & OLS \\
\hline 2004 & OrgSci & Selection & $\begin{array}{l}\text { Heckman } \\
\text { method }\end{array}$ & No & No & Unclear & Unclear & Probit & Hierarchical \\
\hline 2006 & OrgSci & Treatment & $\begin{array}{l}\text { Heckman } \\
\text { method }\end{array}$ & Yes-MT & Yes-MT & Yes & Yes & Probit & OLS \\
\hline
\end{tabular}


TABLE 8 (Continued)

\begin{tabular}{|c|c|c|c|c|c|c|c|c|c|}
\hline Year. & Journal & $\begin{array}{l}\text { Selection/ } \\
\text { treatment }\end{array}$ & $\begin{array}{l}\text { Heckman } \\
\text { method } \\
\text { Or MLE }\end{array}$ & $\begin{array}{l}\text { Reports 1st } \\
\text { stage }\end{array}$ & $\begin{array}{l}\text { Reports 2nd } \\
\text { stage }\end{array}$ & Exclusion & $\begin{array}{l}\text { Instrument } \\
\text { claim }\end{array}$ & First stage & Second stage \\
\hline 2006 & OrgSci & Selection & $\begin{array}{l}\text { Heckman } \\
\text { method }\end{array}$ & Yes-MT & Yes-MT & No & No & Logit & Event \\
\hline 2007 & OrgSci & Selection & $\begin{array}{l}\text { Heckman } \\
\text { method }\end{array}$ & No & No & Unclear & No & Unclear & Event \\
\hline 2008 & OrgSci & Selection & $\begin{array}{l}\text { Heckman } \\
\text { method }\end{array}$ & No & No & Yes & No & Probit & OLS \\
\hline 2008 & OrgSci & Selection & $\begin{array}{l}\text { Heckman } \\
\text { method }\end{array}$ & No & Yes-MT & Yes & No & Probit & OLS \\
\hline 2008 & OrgSci & Selection & $\begin{array}{l}\text { Heckman } \\
\text { method }\end{array}$ & Yes-MT & Yes-MT & Yes & No & Probit & GLS \\
\hline 2008 & OrgSci & Selection & $\begin{array}{l}\text { Heckman } \\
\text { method }\end{array}$ & Yes-MT & Yes-MT & Yes & No & Probit & OLS \\
\hline 2009 & OrgSci & Selection & $\begin{array}{l}\text { Heckman } \\
\text { method }\end{array}$ & No & Yes-MT & Yes & Yes & Logit & Logit \\
\hline 2009 & OrgSci & Selection & $\begin{array}{l}\text { Heckman } \\
\text { method }\end{array}$ & No & No & Yes & No & Probit & Probit \\
\hline 2009 & OrgSci & Selection & $\begin{array}{l}\text { Heckman } \\
\text { method }\end{array}$ & Yes-MT & Yes-MT & Yes & No & Probit & Probit \\
\hline 2010 & OrgSci & Selection & $\begin{array}{l}\text { Heckman } \\
\text { method }\end{array}$ & Yes & Yes-MT & Yes & No & Probit & Probit \\
\hline 2010 & OrgSci & Selection & $\begin{array}{l}\text { Heckman } \\
\text { method }\end{array}$ & No & Yes-MT & Yes & No & Probit & Logit \\
\hline 2010 & OrgSci & Selection & $\begin{array}{l}\text { Heckman } \\
\text { method }\end{array}$ & No & Yes-MT & Unclear & No & Probit & Unclear \\
\hline 2010 & OrgSci & Selection & $\begin{array}{l}\text { Heckman } \\
\text { method }\end{array}$ & Yes-MT & Yes-MT & Yes & Yes & Probit & Hazard \\
\hline 2010 & OrgSci & Selection & $\begin{array}{l}\text { Heckman } \\
\text { method }\end{array}$ & No & No & Unclear & Unclear & Probit & OLS \\
\hline 2011 & OrgSci & Selection & $\begin{array}{l}\text { Heckman } \\
\text { method }\end{array}$ & No & Yes-MT & Unclear & No & Logit & GLS \\
\hline 2011 & OrgSci & Selection & Unclear & Yes-MT & Yes-MT & Yes & No & Probit & Probit \\
\hline 2012 & OrgSci & Selection & $\begin{array}{l}\text { Heckman } \\
\text { method }\end{array}$ & No & Yes-MT & Yes & No & Probit & GLS \\
\hline 2012 & OrgSci & Selection & $\begin{array}{l}\text { Heckman } \\
\text { method }\end{array}$ & Yes & Yes-MT & Yes & No & Probit & Probit \\
\hline 2012 & OrgSci & Selection & $\begin{array}{l}\text { Heckman } \\
\text { method }\end{array}$ & No & Yes-MT & Unclear & No & Unclear & Logit \\
\hline 2013 & OrgSci & Selection & $\begin{array}{l}\text { Heckman } \\
\text { method }\end{array}$ & No & Yes-MT & Yes & No & Probit & Probit \\
\hline 2013 & OrgSci & Selection & $\begin{array}{l}\text { Heckman } \\
\text { method }\end{array}$ & Yes & Yes-MT & Yes & Yes & Probit & $\begin{array}{l}\text { Complementary } \\
\text { log-log }\end{array}$ \\
\hline 2013 & OrgSci & Selection & $\begin{array}{l}\text { Heckman } \\
\text { method }\end{array}$ & No & Yes-MT & Yes & Yes & Probit & NB \\
\hline 2013 & OrgSci & Selection & $\begin{array}{l}\text { Heckman } \\
\text { method }\end{array}$ & Yes-Appendix & Yes-MT & Yes & Yes & Probit & Probit \\
\hline 2013 & OrgSci & Selection & $\begin{array}{l}\text { Heckman } \\
\text { method }\end{array}$ & No & No & Yes & Yes & Probit & OLS \\
\hline 2013 & OrgSci & Selection & $\begin{array}{l}\text { Heckman } \\
\text { method }\end{array}$ & Yes & Yes-MT & Yes & Yes & Probit & NB \\
\hline 2013 & OrgSci & Selection & $\begin{array}{l}\text { Heckman } \\
\text { method }\end{array}$ & No & Yes-MT & No & No & Probit & OLS \\
\hline
\end{tabular}


TABLE 8 (Continued)

\begin{tabular}{|c|c|c|c|c|c|c|c|c|}
\hline Year Journal & $\begin{array}{l}\text { Selection/ } \\
\text { treatment }\end{array}$ & $\begin{array}{l}\text { Heckman } \\
\text { method } \\
\text { Or MLE }\end{array}$ & $\begin{array}{l}\text { Reports 1st } \\
\text { stage }\end{array}$ & $\begin{array}{l}\text { Reports 2nd } \\
\text { stage }\end{array}$ & Exclusion & $\begin{array}{l}\text { Instrument } \\
\text { claim }\end{array}$ & First stage & Second stage \\
\hline 2013 OrgSci & Selection & $\begin{array}{l}\text { Heckman } \\
\text { method }\end{array}$ & No & Yes-MT & Yes & Yes & Probit & OLS \\
\hline 2014 OrgSci & Selection & $\begin{array}{l}\text { Heckman } \\
\text { method }\end{array}$ & No & Yes-MT & Yes & No & Probit & OLS \\
\hline 2014 OrgSci & Selection & $\begin{array}{l}\text { Heckman } \\
\text { method }\end{array}$ & Yes & Yes-MT & Yes & Yes & Probit & NB/Probit \\
\hline 2014 OrgSci & Selection & $\begin{array}{l}\text { Heckman } \\
\text { method }\end{array}$ & Yes-Appendix & Yes-MT & Yes & No & Probit & Probit \\
\hline 2014 OrgSci & Selection & $\begin{array}{l}\text { Heckman } \\
\text { method }\end{array}$ & No & No & Yes & Yes & Probit & OLS \\
\hline 2014 OrgSci & Selection & $\begin{array}{l}\text { Heckman } \\
\text { method }\end{array}$ & No & Yes-MT & Unclear & No & Probit & NB \\
\hline 2014 OrgSci & Selection & $\begin{array}{l}\text { Heckman } \\
\text { method }\end{array}$ & No & Yes-MT & Yes & No & Probit & Poisson \\
\hline 2014 OrgSci & Selection & $\begin{array}{l}\text { Heckman } \\
\text { method }\end{array}$ & No & No & Yes & Yes & Probit & Logit \\
\hline 2015 OrgSci & Selection & $\begin{array}{l}\text { Heckman } \\
\text { method }\end{array}$ & Yes & Yes & Yes & Yes & Probit & OLS \\
\hline 2015 OrgSci & Selection & $\begin{array}{l}\text { Heckman } \\
\text { method }\end{array}$ & Yes & Yes-MT & Yes & No & Probit & Arellano-bond \\
\hline 2015 OrgSci & Selection & $\begin{array}{l}\text { Heckman } \\
\text { method }\end{array}$ & No & Yes-MT & Yes & Yes & Probit & Logit \\
\hline 2015 OrgSci & Selection & $\begin{array}{l}\text { Heckman } \\
\text { method }\end{array}$ & Yes-Appendix & Yes-Appendix & No & No & Probit & OLS \\
\hline 2015 OrgSci & Selection & $\begin{array}{l}\text { Heckman } \\
\text { method }\end{array}$ & Yes & Yes-MT & Yes & Yes & Logit & OLS \\
\hline 2015 OrgSci & Selection & $\begin{array}{l}\text { Heckman } \\
\text { method }\end{array}$ & No & No & Unclear & No & Probit & Exponential \\
\hline 2016 OrgSci & Selection & $\begin{array}{l}\text { Heckman } \\
\text { method }\end{array}$ & No & No & Yes & Yes & Probit & OLS \\
\hline 2016 OrgSci & Selection & $\begin{array}{l}\text { Heckman } \\
\text { method }\end{array}$ & No & Yes-MT & Yes & Yes & Probit & OLS \\
\hline 2016 OrgSci & Selection & $\begin{array}{l}\text { Heckman } \\
\text { method }\end{array}$ & Yes & Yes-MT & No & No & Probit & GLS \\
\hline 2016 OrgSci & Selection & $\begin{array}{l}\text { Heckman } \\
\text { method }\end{array}$ & Yes & Yes-MT & Yes & No & Probit & GLS \\
\hline 2016 OrgSci & Selection & $\begin{array}{l}\text { Heckman } \\
\text { method }\end{array}$ & Yes-Appendix & Yes-MT & Yes & Yes & Probit & OLS \\
\hline 1998 SMJ & Selection & MLE & No & No & Unclear & Unclear & Probit & ML \\
\hline 1999 SMJ & Selection & $\begin{array}{l}\text { Heckman } \\
\text { method }\end{array}$ & No & No & Unclear & Unclear & Probit & Logit \\
\hline 2000 SMJ & Selection & Unclear & No & No & Unclear & No & Unclear & GLS \\
\hline $2002 \mathrm{SMJ}$ & Selection & $\begin{array}{l}\text { Heckman } \\
\text { method }\end{array}$ & No & Yes-MT & Unclear & No & Probit & OLS \\
\hline $2002 \mathrm{SMJ}$ & Selection & $\begin{array}{l}\text { Heckman } \\
\text { method }\end{array}$ & Yes-MT & Yes-MT & Yes & No & Probit & OLS \\
\hline $2002 \mathrm{SMJ}$ & Selection & $\begin{array}{l}\text { Heckman } \\
\text { method }\end{array}$ & No & No & Unclear & Unclear & Probit & GLS \\
\hline 2003 SMJ & Selection & $\begin{array}{l}\text { Heckman } \\
\text { method }\end{array}$ & Yes-MT & Yes-MT & Yes & Yes & Probit & OLS \\
\hline
\end{tabular}


TABLE 8 (Continued)

\begin{tabular}{|c|c|c|c|c|c|c|c|c|c|}
\hline Year & Journal & $\begin{array}{l}\text { Selection/ } \\
\text { treatment }\end{array}$ & $\begin{array}{l}\text { Heckman } \\
\text { method } \\
\text { Or MLE }\end{array}$ & $\begin{array}{l}\text { Reports 1st } \\
\text { stage }\end{array}$ & $\begin{array}{l}\text { Reports 2nd } \\
\text { stage }\end{array}$ & Exclusion & $\begin{array}{l}\text { Instrument } \\
\text { claim }\end{array}$ & First stage & Second stage \\
\hline 2003 & SMJ & Selection & $\begin{array}{l}\text { Heckman } \\
\text { method }\end{array}$ & No & No & Yes & Yes & Probit & OLS \\
\hline 2003 & $\mathrm{SMJ}$ & Selection & $\begin{array}{l}\text { Heckman } \\
\text { method }\end{array}$ & No & No & No & No & Probit & Probit \\
\hline 2004 & SMJ & Selection & $\begin{array}{l}\text { Heckman } \\
\text { method }\end{array}$ & No & No & Yes & No & Probit & OLS \\
\hline 2004 & SMJ & Selection & $\begin{array}{l}\text { Heckman } \\
\text { method }\end{array}$ & No & Yes-MT & Unclear & No & Probit & OLS \\
\hline 2004 & SMJ & Selection & $\begin{array}{l}\text { Heckman } \\
\text { method }\end{array}$ & No & No & Unclear & Unclear & Probit & GLS \\
\hline 2004 & SMJ & Selection & $\begin{array}{l}\text { Heckman } \\
\text { method }\end{array}$ & Yes-MT & Yes-MT & No & No & Probit & OLS \\
\hline 2005 & SMJ & Selection & $\begin{array}{l}\text { Heckman } \\
\text { method }\end{array}$ & Yes-MT & Yes-MT & No & No & Probit & OLS \\
\hline 2005 & SMJ & Selection & $\begin{array}{l}\text { Heckman } \\
\text { method }\end{array}$ & Yes-MT & Yes-MT & Yes & Yes & Probit & OLS \\
\hline 2006 & SMJ & Selection & $\begin{array}{l}\text { Heckman } \\
\text { method }\end{array}$ & Yes-MT & Yes-MT & Yes & No & Probit & OLS \\
\hline 2006 & SMJ & Selection & $\begin{array}{l}\text { Heckman } \\
\text { method }\end{array}$ & No & Yes-MT & Unclear & Unclear & Hazard & GEE \\
\hline 2006 & SMJ & Selection & $\begin{array}{l}\text { Heckman } \\
\text { method }\end{array}$ & Yes-MT & Yes-MT & Yes & Yes & Probit & OLS \\
\hline 2006 & SMJ & Selection & $\begin{array}{l}\text { Heckman } \\
\text { method }\end{array}$ & Yes-MT & Yes-MT & Yes & Yes & Probit & WLS \\
\hline 2006 & SMJ & Selection & Unclear & No & Yes-MT & Unclear & Unclear & Probit & Probit \\
\hline 2007 & SMJ & Selection & $\begin{array}{l}\text { Heckman } \\
\text { method }\end{array}$ & Yes-MT & Yes-MT & No & No & Probit & OLS \\
\hline 2007 & $\mathrm{SMJ}$ & Selection & $\begin{array}{l}\text { Heckman } \\
\text { method }\end{array}$ & No & Yes-MT & Yes & No & Event history & OLS \\
\hline 2007 & SMJ & Selection & $\begin{array}{l}\text { Heckman } \\
\text { method }\end{array}$ & Yes-MT & Yes-MT & Yes & Yes & Probit & OLS \\
\hline 2008 & SMJ & Selection & $\begin{array}{l}\text { Heckman } \\
\text { method }\end{array}$ & No & No & No & No & Logit & OLS \\
\hline 2008 & SMJ & Selection & MLE & Yes-MT & Yes-MT & Yes & No & Probit & Probit \\
\hline 2008 & SMJ & Treatment & $\begin{array}{l}\text { Heckman } \\
\text { method }\end{array}$ & No & Yes-MT & Unclear & No & Probit & Hazard \\
\hline 2010 & $\mathrm{SMJ}$ & Selection & $\begin{array}{l}\text { Heckman } \\
\text { method }\end{array}$ & Yes-MT & Yes-MT & No & No & Probit & OLS \\
\hline 2010 & SMJ & Selection & $\begin{array}{l}\text { Heckman } \\
\text { method }\end{array}$ & Yes-MT & Yes-MT & Yes & No & Logit & OLS \\
\hline 2010 & SMJ & Treatment & $\begin{array}{l}\text { Heckman } \\
\text { method }\end{array}$ & Yes-MT & Yes-MT & No & No & Probit & Logit \\
\hline 2010 & SMJ & Selection & $\begin{array}{l}\text { Heckman } \\
\text { method }\end{array}$ & No & Yes-MT & Yes & Yes & Logit & Hazard \\
\hline 2010 & SMJ & Selection & $\begin{array}{l}\text { Heckman } \\
\text { method }\end{array}$ & Yes-MT & Yes-MT & Yes & Yes & Relogit & Relogit \\
\hline 2010 & SMJ & Selection & $\begin{array}{l}\text { Heckman } \\
\text { method }\end{array}$ & No & Yes-MT & Yes & Yes & Probit & OLS \\
\hline 2011 & SMJ & Selection & $\begin{array}{l}\text { Heckman } \\
\text { method }\end{array}$ & No & No & Unclear & Unclear & Probit & OLS \\
\hline
\end{tabular}


TABLE 8 (Continued)

\begin{tabular}{|c|c|c|c|c|c|c|c|c|}
\hline Year Journal & $\begin{array}{l}\text { Selection/ } \\
\text { treatment }\end{array}$ & $\begin{array}{l}\text { Heckman } \\
\text { method } \\
\text { Or MLE }\end{array}$ & $\begin{array}{l}\text { Reports 1st } \\
\text { stage }\end{array}$ & $\begin{array}{l}\text { Reports 2nd } \\
\text { stage }\end{array}$ & Exclusion & $\begin{array}{l}\text { Instrument } \\
\text { claim }\end{array}$ & First stage & Second stage \\
\hline 2012 SMJ & Selection & $\begin{array}{l}\text { Heckman } \\
\text { method }\end{array}$ & Yes-MT & Yes-MT & Yes & Yes & Probit & OLS \\
\hline 2012 SMJ & Selection & $\begin{array}{l}\text { Heckman } \\
\text { method }\end{array}$ & No & Yes-MT & Yes & Yes & Probit & Poisson \\
\hline 2012 SMJ & Selection & $\begin{array}{l}\text { Heckman } \\
\text { method }\end{array}$ & No & No & Unclear & No & Probit & GLS \\
\hline 2013 SMJ & Selection & $\begin{array}{l}\text { Heckman } \\
\text { method }\end{array}$ & No & Yes-MT & Yes & No & Event history & OLS \\
\hline 2013 SMJ & Treatment & $\begin{array}{l}\text { Heckman } \\
\text { method }\end{array}$ & Yes & Yes-MT & Yes & Yes & Probit & OLS \\
\hline 2013 SMJ & Selection & $\begin{array}{l}\text { Heckman } \\
\text { method }\end{array}$ & No & No & No & No & Probit & Cox \\
\hline 2013 SMJ & Selection & $\begin{array}{l}\text { Heckman } \\
\text { method }\end{array}$ & Yes & Yes-MT & Yes & Yes & Probit & OLS \\
\hline 2014 SMJ & Selection & $\begin{array}{l}\text { Heckman } \\
\text { method }\end{array}$ & No & Yes-MT & Yes & No & Probit & SUR \\
\hline 2014 SMJ & Selection & $\begin{array}{l}\text { Heckman } \\
\text { method }\end{array}$ & No & No & Unclear & No & Probit & Hierarchical \\
\hline 2014 SMJ & Selection & $\begin{array}{l}\text { Heckman } \\
\text { method }\end{array}$ & No & Yes-MT & Unclear & No & Probit & OLS \\
\hline 2014 SMJ & Selection & $\begin{array}{l}\text { Heckman } \\
\text { method }\end{array}$ & No & No & No & No & Probit & GLS \\
\hline 2014 SMJ & Selection & $\begin{array}{l}\text { Heckman } \\
\text { method }\end{array}$ & No & Yes-MT & Yes & Yes & Probit & Cox \\
\hline 2014 SMJ & Selection & $\begin{array}{l}\text { Heckman } \\
\text { method }\end{array}$ & No & No & Yes & No & Probit & GLS \\
\hline 2014 SMJ & Selection & $\begin{array}{l}\text { Heckman } \\
\text { method }\end{array}$ & No & No & Yes & No & Probit & Growth model \\
\hline 2014 SMJ & Selection & $\begin{array}{l}\text { Heckman } \\
\text { method }\end{array}$ & Yes & Yes-MT & No & No & Discrete time & Ordered Probit \\
\hline 2014 SMJ & Selection & $\begin{array}{l}\text { Heckman } \\
\text { method }\end{array}$ & No & Yes-MT & Yes & No & Probit & ML \\
\hline 2014 SMJ & Selection & $\begin{array}{l}\text { Heckman } \\
\text { method }\end{array}$ & No & Yes-MT & Unclear & No & Probit & OLS \\
\hline 2015 SMJ & Selection & $\begin{array}{l}\text { Heckman } \\
\text { method }\end{array}$ & Yes & Yes-MT & Yes & Yes & Probit & OLS \\
\hline 2015 SMJ & Selection & $\begin{array}{l}\text { Heckman } \\
\text { method }\end{array}$ & No & Yes & Unclear & No & Probit & Ordered Logit \\
\hline 2015 SMJ & Selection & $\begin{array}{l}\text { Heckman } \\
\text { method }\end{array}$ & No & No & Yes & No & Probit & OLS \\
\hline 2015 SMJ & Selection & $\begin{array}{l}\text { Heckman } \\
\text { method }\end{array}$ & No & No & Unclear & No & Probit & OLS \\
\hline 2015 SMJ & Selection & $\begin{array}{l}\text { Heckman } \\
\text { method }\end{array}$ & No & Yes-MT & Yes & No & Probit & GLS \\
\hline 2015 SMJ & Selection & $\begin{array}{l}\text { Heckman } \\
\text { method }\end{array}$ & Yes & Yes-MT & Yes & No & Probit & OLS \\
\hline 2015 SMJ & Selection & $\begin{array}{l}\text { Heckman } \\
\text { method }\end{array}$ & Yes-Appendix & Yes-MT & No & No & Probit & Hazard \\
\hline 2015 SMJ & Selection & $\begin{array}{l}\text { Heckman } \\
\text { method }\end{array}$ & No & Yes-MT & No & No & Probit & NB \\
\hline
\end{tabular}


TABLE 8 (Continued)

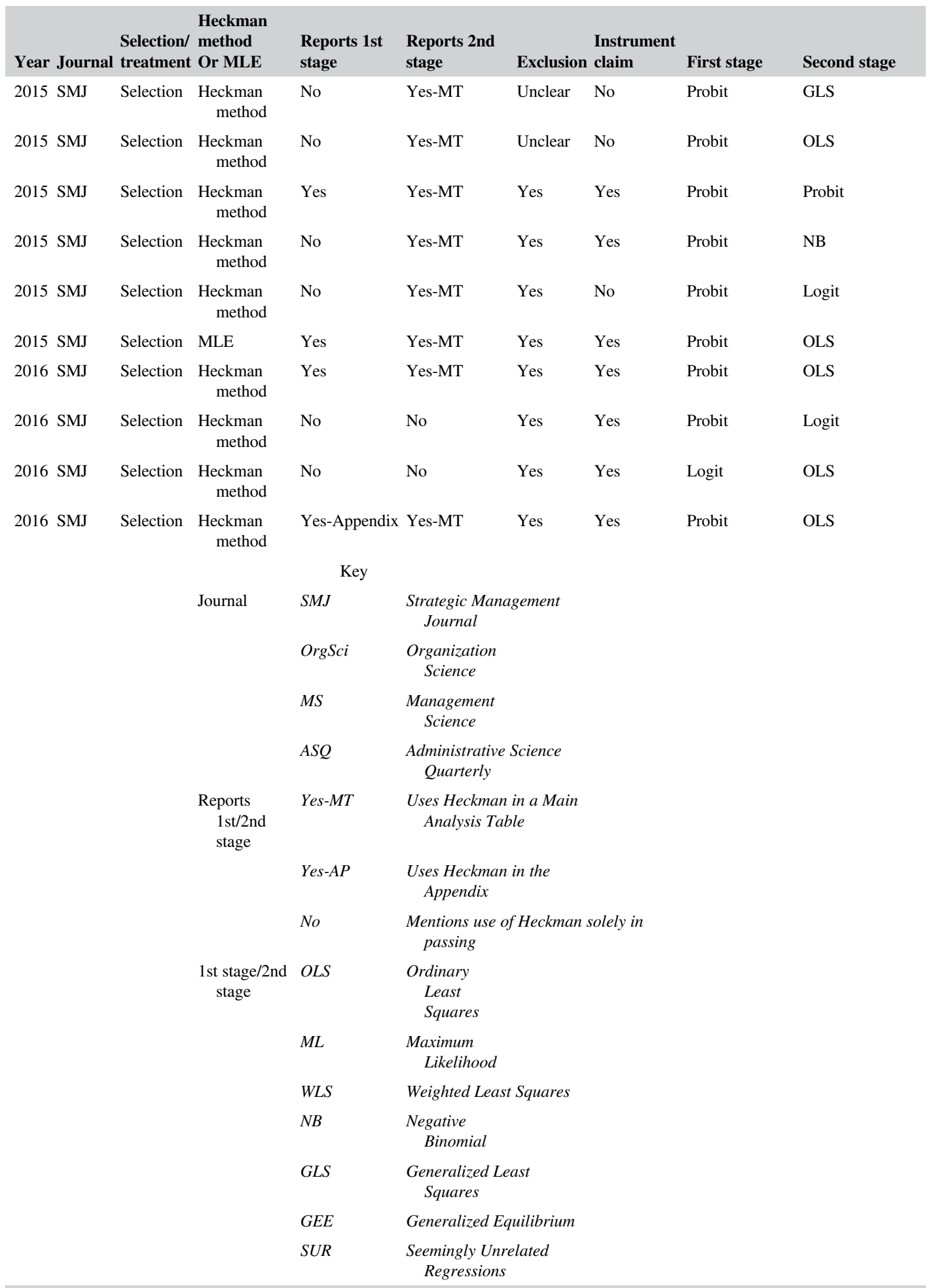


TABLE 9 Papers citing Heckman (1979) by year

\begin{tabular}{|c|c|c|c|}
\hline Year & Number of cites & Percentage with clear exclusion & Percentage claiming an instrument \\
\hline 1997 & 3 & $33.33 \%$ & $0.00 \%$ \\
\hline 1998 & 2 & $50.00 \%$ & $50.00 \%$ \\
\hline 1999 & 3 & $0.00 \%$ & $0.00 \%$ \\
\hline 2000 & 1 & $0.00 \%$ & $0.00 \%$ \\
\hline 2001 & 2 & $100.00 \%$ & $0.00 \%$ \\
\hline 2002 & 6 & $16.67 \%$ & $0.00 \%$ \\
\hline 2003 & 6 & $66.67 \%$ & $33.33 \%$ \\
\hline 2004 & 6 & $16.67 \%$ & $0.00 \%$ \\
\hline 2005 & 2 & $50.00 \%$ & $50.00 \%$ \\
\hline 2006 & 10 & $70.00 \%$ & $60.00 \%$ \\
\hline 2007 & 5 & $40.00 \%$ & $20.00 \%$ \\
\hline 2008 & 9 & $55.56 \%$ & $0.00 \%$ \\
\hline 2009 & 9 & $66.67 \%$ & $44.44 \%$ \\
\hline 2010 & 12 & $58.33 \%$ & $33.33 \%$ \\
\hline 2011 & 5 & $40.00 \%$ & $20.00 \%$ \\
\hline 2012 & 9 & $55.56 \%$ & $33.33 \%$ \\
\hline 2013 & 17 & $70.59 \%$ & $58.82 \%$ \\
\hline 2014 & 20 & $70.00 \%$ & $35.00 \%$ \\
\hline 2015 & 26 & $69.23 \%$ & $34.62 \%$ \\
\hline 2016 & 12 & $83.33 \%$ & $66.67 \%$ \\
\hline Total & 165 & $55.76 \%$ & $32.73 \%$ \\
\hline
\end{tabular}

stricter criteria, at most four of the articles have sufficient justification. Also, Table 8 shows that many of the papers are unclear about use of the Heckman method, in terms of both the variables and the method used.

Finally, numerous methods are employed in the two stages. As noted earlier, the appropriate method in the first stage is probit. However, Lee (1983) asserts that using logit in the first stage along with ordinary least squares in the second stage can also result in consistent estimates. An even wider variety of methods is employed in the second stage. Van de Ven and Van Praag (1981), examining the statistical properties of using a probit in the second stage, conclude that the Heckman two-step method can be employed in this instance given the normality of the second-stage errors. Other than probit, we are unaware of other second-stage estimation techniques besides OLS that have desirable statistical properties. Since the derivation of the Heckman two-step method relies on the normality of errors, we are hesitant to suggest that the use of other estimation techniques is appropriate.

However, as discussed in Section 2, maximum likelihood can also be used to estimate both equations simultaneously. This alternative to the Heckman two-step method is distinguished in Table 8,

TABLE 10 Papers citing Heckman (1979) by journal

\begin{tabular}{lcll} 
Journal & Number of cites & Percentage with clear exclusion & Percentage claiming an instrument \\
ASQ & 23 & $39.13 \%$ & $21.74 \%$ \\
MS & 24 & $66.67 \%$ & $50.00 \%$ \\
OrgSci & 50 & $74.00 \%$ & $36.00 \%$ \\
SMJ & 68 & $54.41 \%$ & $32.35 \%$ \\
Total & 165 & $55.76 \%$ & $32.73 \%$ \\
\hline
\end{tabular}


and includes second-stage estimation techniques such as a Poisson model. Since it does not rely on the statistical properties of the inverse Mills ratio, we do not focus on the methods employed except to note that maximum likelihood does not eliminate the need for an instrument in the first stage; the underlying model is the same and solely the estimation technique differs. In fact, Heckman (1978) suggests that the Heckman two-step method should be useful in generating initial consistent estimators for the maximum-likelihood technique.

Given that Strategic Organization published both Hamilton and Nickerson (2003) and Bascle (2008), we report in Table 11 whether recent papers in Strategic Organization have more correctly employed the Heckman two-step method. Of the 10 Strategic Organization articles since 2005 that cite Heckman (1979), all but one incorporate an exclusion restriction. Only five of the 10 explicitly address why the instrument is valid, but the Heckman two-step method is discussed and presented more clearly in Strategic Organization.

\section{5 | EMPIRICAL ANALYSIS}

\section{1 | Overview of the empirical setting}

Shaver (1998), among the most frequently cited papers on use of the Heckman two-step method in strategy research, made important methodological contributions by emphasizing the need to control for endogeneity in strategic decision-making. The paper discusses the prevalence of endogeneity in strategy research: because managers make strategic decisions conditional on firm-specific factors, self-selection occurs (Shaver, 1998). Thus, not controlling for this heterogeneity results in biased and inconsistent estimates of the effects of strategic decisions. In this section, we will revisit the classic global strategy question addressed in this seminal work to demonstrate the triangulation of approaches we suggest to future researchers, as illustrated in Figure 1.

Shaver (1998) employs the Heckman two-step method in examining the performance impact of greenfield versus acquisition when a firm enters a foreign market. He argues for the importance of controlling for self-selection, because firms whose characteristics make them more likely to succeed in greenfield will choose that strategy, while the same will hold true for acquisition. Thus, Shaver runs a probit model on the entry mode choice as a first step. The independent variables in this step are pre-entry industry growth and other exogenous factors. The second step uses five-year survival as a performance measure.

Though it seems plausible that pre-entry industry growth solely affects selection, it could also affect performance as measured by survival in a number of ways. For example, if pre-entry growth is high and post-entry growth is low, the firm might be less likely to exit the industry than if pre-entry growth and post-entry growth were both low. Also, pre-entry industry growth is not a significant determinant of the choice of entry mode in one of the selection models (Shaver, 1998). Thus, even in this seminal work, opportunity exists to perform further robustness checks by using multiple methods, verifying the validity of the instrument, and testing possible additional instruments. In our analysis, we will examine a second possible instrument to validate results, following the third step in Figure 1 to consider multiple options for the exclusion restriction.

Our empirical setting is the outward foreign direct-investment decisions of U.S. firms. We consider the decision to enter via acquisition or greenfield, and closely replicate the controls and analysis performed by Shaver (1998). For example, as we are considering outward rather than inward FDI, we include country fixed effects in order to follow Shaver (1998) more directly and eliminate the need for additional country-specific variables. We use the Department of Commerce's Bureau of 


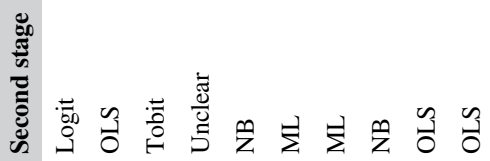

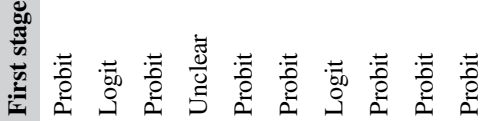

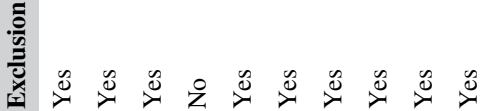

表

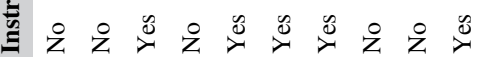

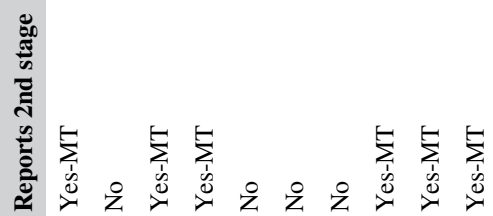

$\frac{\sqrt{2}}{\frac{1}{20}}$

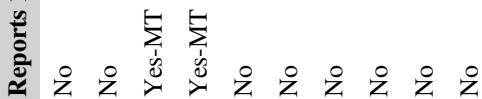

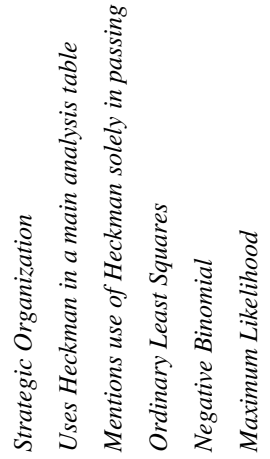

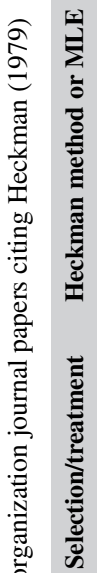

19.

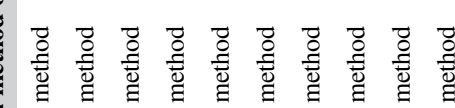

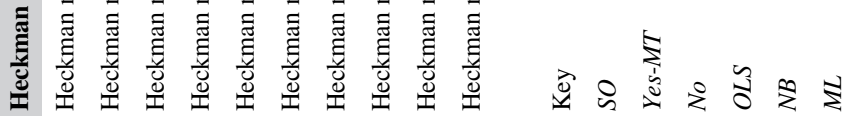

焉

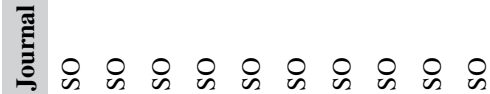

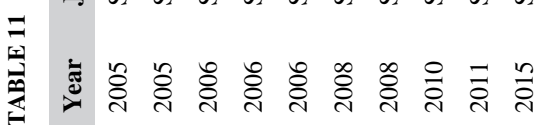


Economic Analysis (BEA) firm-level data on the activities of U.S. multinational enterprises, consisting of U.S. parent companies and their foreign affiliates, to identify new acquisitions and greenfield investments by the 1989 and 1994 cohorts of firms. Following our guidelines in Figure 1, we thus have established that our analysis will suffer from selection, as discussed previously in Shaver (1998), and that our data follows the treatment selection, as we have performance data for both new acquisitions and greenfield investments. We also obtain detailed industry and country characteristics from the World Development Indicators data. Finally, Compustat provides firm-level financial data to supplement these two sources. Our variables and their definitions and sources follow.

\subsection{1 | Dependent variable}

Dead, from the BEA's firm-level data, is an indicator variable designated as one when the firm is no longer operating in the host country 5 years later. Our second-stage performance outcome is whether or not the firm survives for 5 years. Shaver (1998) similarly looks at survival as the performance outcome.

\subsubsection{Independent variable}

New greenfield, from the BEA's firm-level data, is an indicator designated as one if the firm enters on its own, rather than through acquisition. Because our aim is to assess the performance implications of entry-mode choice, this is the main variable of interest. We will utilize various techniques to instrument for selection issues with this variable in the first stage.

\subsection{3 | First-stage instruments}

WDI retrospective 5-year growth rate, from the World Development Indicators, consists of the growth rate of the industry in the host country over the 5 years prior to entry. This variable mimics the instrument used by Shaver (1998), and has been examined in prior work, including Hennart and Park (1993) and Zejan (1990). Its rationale is that the industry's prior growth ought to affect the availability of suitable acquisition targets, but not necessarily survival, and thus can be used as an instrument in the first-stage regression to predict greenfield entry.

Host-country greenfield proportion in 1989, from the BEA's firm-level data, is the proportion of host-country affiliates of U.S. multinational firms that entered via greenfield in 1989. The rationale for this instrument is that institutional norms may pressure firms into a selection decision based on peer patterns that lack clear causal connection to future focal-firm performance. Thus, this variable can serve as a second instrument that affects entry-mode choice in the first stage but not survival in the second stage.

Note that in our discussion of these two instruments, we follow the guidelines of the third step in our Figure 1, and utilize our knowledge of the context, as well as previous research, to guide our search for multiple exclusion restrictions and describe their validity. In addition, we will perform OLS analysis in addition to the Heckman method with these exclusion restrictions to triangulate our results. Thus, we consider both the "Ordinary Least Squares" and "Heckman method" branches of Figure 1, and use the context to test and describe multiple instruments, as well as the expected direction of any bias from unobserved selection.

\subsection{4 | Controls}

WDI forward 5-year growth rate, from the World Development Indicators, captures the industry growth rate for 5 years after the choice of entry mode, a broad indicator of how favorable industry conditions were (Wagner, 1994).

Number of affiliates in the host country, constructed from the BEA data, captures the number of a given corporation's other affiliates in the same country. This variable could affect both entry mode 
and performance: firms with more experience in a country may make more informed entry-mode choices and thus be more likely to survive. Prior work indicates that firms with more experience are more likely to choose acquisition (Caves \& Mehra, 1986).

Host country Herfindahl US MNCs, constructed from BEA data on foreign affiliate sales, captures the concentration of U.S. MNCs' affiliates in a given host country and a given year. More concentrated values may indicate stiffer competition among U.S. competitors, which would lower survival rates but also increase the likelihood of greenfield entry (Hennart \& Park, 1993).

Log of parent company global sales, from Compustat, captures the size of an organization. Affiliates backed by larger companies may have more capacity to enter via greenfield and to sustain downturns and thus survive. Prior research has found conflicting evidence regarding the effect of size on entry-mode choice. ${ }^{13}$

Parent $R \& D$ intensity comes from Compustat. We control for this variable as prior research has found that more R\&D-intensive companies are more likely to pursue greenfield entry (Hennart \& Park, 1993), and potentially to survive entry, because they tend to offer more differentiated products.

Entry in the same three-digit industry, host-country, and year, from the BEA data, captures the number of other new entrants in the same industry, country, and year. This variable thus captures unobservable factors other than industry growth rate that may indicate that an industry is particularly favorable for entry.

Table 12 presents summary statistics on these key variables. First, we note that we have sufficient variation in our key outcome variable, as more than a third of firms are classified as Dead. In addition, our explanatory variable of entering via Greenfield captures slightly more than half of the firms, providing explanatory power for both entry mode choices. Finally, we see variation in many of the firm characteristics, including large ranges in the number of affiliates in the host country and R\&D intensity, for example. This suggests that controlling for these differences when estimating the performance implications of entry-mode choice is essential.

Table 13 presents the correlation matrix of these variables. Here, the pairwise correlations reveal that firms entering via greenfield are correlated with a $4.8 \%$ higher chance of survival (corresponding to the -0.048 correlation between Dead and New Greenfield). Firms with more affiliates in the host country, and those with higher R\&D intensity, are also associated with higher survival. At the country level, survival is more likely if the industry exhibits a lower density of competitors, a lower

TABLE 12 Summary statistics

\begin{tabular}{lrrrrrr} 
& Mean & Median & \multicolumn{1}{c}{$\boldsymbol{S D}$} & \multicolumn{1}{c}{ Min } & Max & Obs \\
[1] Dead & 0.348 & 0.000 & 0.476 & 0.000 & 1.000 & 2,459 \\
[2] New greenfield & 0.537 & 1.000 & 0.499 & 0.000 & 1.000 & 2,459 \\
[3] WDI forward 5 year growth rate & 3.070 & 2.85 & 1.804 & -1.048 & 12.920 & 2,459 \\
[4] Number of affiliates in host country & 853.196 & 692 & 663.051 & 1.000 & $2,296.000$ & 2,459 \\
[5] Host country Herfindahl USMNCs & 0.381 & 0.273 & 0.301 & 0.040 & 1.732 & 2,459 \\
[6] Log of parent company global sales & 15.397 & 15.642 & 1.832 & 5.460 & 18.897 & 2,459 \\
[7] Parent and intensity & 2.316 & 0.771 & 3.804 & 0.000 & 44.514 & 2,459 \\
[8] Entry in same three digit industry, host-country, and year & 1.149 & 0.000 & 2.583 & 0.000 & 20.000 & 2,459
\end{tabular}

\footnotetext{
${ }^{13}$ See Kogut and Singh (1988) and Caves and Mehra (1986).
} 
TABLE 13 Correlation matrix

\begin{tabular}{|c|c|c|c|c|c|c|c|}
\hline & [1] & [2] & [3] & [4] & [5] & [6] & [7] \\
\hline [1] Dead & 1.000 & & & & & & \\
\hline [2] New greenfield & -0.048 & 1.000 & & & & & \\
\hline [3] WDI forward 5 year growth rate & 0.076 & 0.199 & 1.000 & & & & \\
\hline [4] Number of affiliates in host country & -0.053 & 0.136 & -0.336 & 1.000 & & & \\
\hline [5] Host country Herfindahl USMNCs & 0.091 & 0.014 & -0.110 & 0.078 & 1.000 & & \\
\hline [6] Log of parent company global sales & 0.027 & 0.023 & -0.011 & -0.119 & -0.042 & 1.000 & \\
\hline [7] Parent and intensity & -0.215 & -0.037 & 0.050 & -0.195 & 0.004 & -0.016 & 1.000 \\
\hline $\begin{array}{l}\text { [8] Entry in same three digit industry, host-country, } \\
\text { and year }\end{array}$ & -0.059 & 0.603 & -0.013 & 0.037 & -0.038 & 0.054 & 0.056 \\
\hline
\end{tabular}

5-year growth rate, or higher entry in the same year. These characteristics may mean lower competition is overall more favorable, with the caveat that higher entry indicates better industry conditions.

\section{2 | Empirical analysis and results}

First, we examine standard OLS models to determine the performance implications of greenfield entry on survival without any controls for selection. Column 1 of Table 14 reports the OLS of the Dead indicator on the greenfield indicator, as well as the other second-stage controls, with no fixed effects. We find a negative value on the greenfield indicator, whose magnitude suggests that firms that enter via greenfield are $4.8 \%$ more likely to survive than those that enter via acquisition. In Column 2, which adds country fixed effects, the result stays largely the same. Regardless of the preferred

TABLE 14 OLS models

\section{OLS}

OLS FE

\section{DV: Dead}

New greenfield

$-0.048$

$-0.045$

[0.019]

[0.020]

WDI forward 5 year growth rate

$-0.010$

$-0.021$

[0.005]

[0.013]

Host country Herfindahl USMNCs

$-0.152$

$-0.082$

[0.032]

[0.036]

Log of parent company global sales

0.027

0.028

[0.005]

[0.005]

Parent and intensity

0.002

0.003

[0.002]

[0.003]

Entry in same three digit industry, host-country, and year

$-0.042$

$-0.046$

[0.004]

[0.004]

Country fixed effects included

No

Yes

Industry-year fixed effects included

No

No

$p$ Value

0.000

0.000

Adjusted $R^{2}$

0.068

0.082

Obs

2,461

2,461

Note: SEs are listed below coefficients in parenthesis. 
TABLE 15 Heckman treatment regression models

\begin{tabular}{|c|c|c|c|}
\hline DV: Dead & Model 1 & Model 2 & Model 3 \\
\hline \multirow[t]{2}{*}{ New greenfield } & -0.188 & -0.066 & -0.088 \\
\hline & {$[0.078]$} & [0.034] & {$[0.037]$} \\
\hline \multirow[t]{2}{*}{ WDI forward 5 year growth rate } & 0.017 & 0.159 & 0.014 \\
\hline & [0.022] & [0.013] & {$[0.020]$} \\
\hline \multirow[t]{2}{*}{ Number of affiliates in host country } & - & $1.744 \mathrm{e}-04$ & $1.468 \mathrm{e}-04$ \\
\hline & - & {$[4.75 \mathrm{e}-05]$} & {$[5.63 \mathrm{e}-05]$} \\
\hline \multirow[t]{2}{*}{ Host country Herfindahl USMNCs } & -0.185 & -0.004 & 0.002 \\
\hline & {$[0.163]$} & [0.042] & [0.044] \\
\hline \multirow[t]{2}{*}{ Log of parent company global sales } & 0.078 & 0.013 & 0.014 \\
\hline & [0.026] & {$[0.006]$} & [0.006] \\
\hline \multirow[t]{2}{*}{ Parent and intensity } & 0.003 & 0.001 & 0.001 \\
\hline & {$[0.010]$} & [0.003] & [0.003] \\
\hline \multirow[t]{2}{*}{ Entry in same three digit industry, host-country, and year } & -0.090 & -0.018 & -0.017 \\
\hline & {$[0.035]$} & {$[0.004]$} & {$[0.004]$} \\
\hline \multirow[t]{2}{*}{ Inverse mills ratio } & 1.151 & - & - \\
\hline & {$[0.385]$} & - & - \\
\hline Country-year fixed effects included & No & Yes & Yes \\
\hline Industry fixed effects included & Yes & Yes & Yes \\
\hline Year fixed effects includes & Yes & Yes & Yes \\
\hline$p$ value & 0.001 & 0.000 & 0.000 \\
\hline Log pseudo likelihood & 0.185 & $-2,888.595$ & $-2,769.306$ \\
\hline Obs & 2,150 & 2,461 & 2,344 \\
\hline \multicolumn{4}{|l|}{ First stage: } \\
\hline \multicolumn{4}{|l|}{ DV: New greenfield } \\
\hline \multirow[t]{2}{*}{ WDI retrospective 5 year growth rate } & 0.045 & 0.017 & 0.034 \\
\hline & {$[0.013]$} & {$[0.009]$} & {$[0.012]$} \\
\hline \multirow[t]{2}{*}{ Number of affiliates in host country } & $-1.918 \mathrm{e}-04$ & $-2.272 \mathrm{e}-04$ & $-1.001 \mathrm{e}-04$ \\
\hline & {$[5.51 \mathrm{e}-05]$} & {$[5.43 \mathrm{e}-05]$} & {$[5.98 \mathrm{e}-05]$} \\
\hline \multirow[t]{2}{*}{ Host country Herfindahl USMNCs } & 0.060 & 0.091 & -0.039 \\
\hline & {$[0.108]$} & {$[0.108]$} & {$[0.115]$} \\
\hline \multirow[t]{2}{*}{ Log of parent company global sales } & 0.049 & 0.049 & 0.048 \\
\hline & {$[0.018]$} & {$[0.018]$} & {$[0.018]$} \\
\hline \multirow[t]{2}{*}{ Parent and intensity } & -0.002 & -0.001 & 0.002 \\
\hline & [0.009] & [0.009] & [0.009] \\
\hline \multirow[t]{2}{*}{ Entry in same three digit industry, host-country, and year } & 0.072 & 0.070 & 0.067 \\
\hline & {$[0.012]$} & {$[0.011]$} & {$[0.011]$} \\
\hline \multirow[t]{2}{*}{ Into host greenfield 1989 proportion } & - & - & 0.012 \\
\hline & - & - & {$[0.002]$} \\
\hline$p$ value & 0.000 & - & - \\
\hline Pseudo $R^{2}$ & 0.031 & - & - \\
\hline Wald test of independent equations & - & 0.495 & 0.164 \\
\hline
\end{tabular}

Note: SEs are listed below coefficients in parenthesis. 
final model, running a baseline OLS model, and verifying that the bias occurs in the expected direction as compared to when selection is addressed, is a valuable exercise.

We then move on to the regressions using the Heckman method. Table 15, Column 1 performs the two-stage Heckman method with industry-year fixed effects, using the first-stage regression to generate the inverse Mills ratio, which is then added into the second-stage regression. Columns 2 and 3 perform the treatment regressions simultaneously, using different instrumental variables. In Column 1 , we see that the excluded variable, the retrospective growth rate, is meaningfully different from zero, suggesting that it passes the test of relevance in the first stage. The inverse Mills ratio also has a 95\% confidence interval that does not include zero, which is reassuring but not sufficient to ensure that the Heckman method is being implemented correctly. The coefficient of greenfield in Column 1 is negative and suggests that entrance via greenfield is associated with an $18.8 \%$ increase in the likelihood of survival. In Column 2 we repeat the analysis using maximum likelihood estimation, and include country-year, industry, and year fixed effects. Finally, Column 3 adds the new instrument of the prior greenfield proportion in the host country to capture institutional pressure toward one entrymode choice or the other. Columns 2 and 3 have coefficients of comparable magnitudes, suggesting that the greenfield entry mode is associated with a 6.6 or $8.8 \%$ higher likelihood of survival. The instrument of prior growth rate in Column 2 has a larger standard error than our new instrument of prior greenfield proportion in the host country in Column 3. Thus, our approach suggests the usefulness of our new instrument, as it remains meaningfully different from zero despite the more robust use of maximum likelihood and fixed effects. Furthermore, the consistency of the estimate of the performance implication of greenfield entry across the two instruments provides further support for the conclusion that greenfield entry is associated with a higher likelihood of survival for U.S. MNCs going abroad. Comparing these estimates with those from the OLS regressions, we see that new greenfield has an even stronger effect on survival once controlling for selection. Consistent with the final step of our Figure 1, this triangulation of approaches and careful comparison of methods increases our confidence in the result and is how we suggest the Heckman method be used in future research.

\section{6 | CONCLUSIONS AND SUGGESTIONS}

"There appears to be no automatic way to diagnose and correct sample selection bias. Analytical methods cannot make imperfect data perfect" (Stolzenberg \& Relles, 1997, p. 504).

Given that strategy and organizational theory research has been criticized for its lack of rigorous econometric techniques, the increasing use of instrumental variable and selection methods, such as the Heckman two-step method, is important to the development of the field (Hamilton \& Nickerson, 2003). Though the Heckman two-step method is a pioneering way to deal with selection issues, numerous follow-up studies in economics demonstrated its potential pitfalls. In management strategy research, Bascle (2008) clearly specifies the cases in which the Heckman two-step method is appropriate: when the errors follow a bivariate normal distribution, when the aforementioned exclusion restrictions hold, when the sample is large, and after collinearity is analyzed (Bascle, 2008). Our paper illustrates that the results using the Heckman model are often less reliable than OLS results when these conditions do not hold. Thus, we recommend authors employ one, or ideally more than one, of the alternative approaches outlined below. 
First, one needs to consider whether or not selection is an issue. Stolzenberg and Relles (1997) specify a ratio of estimated selection bias to sampling error that can be used to quantify the amount of selection bias. If this ratio is not satisfied, but selection occurs on observable variables, propensityscore matching is an appropriate technique. ${ }^{14}$ Propensity-score matching is now easily employed using psmatch2 in Stata (Leuven \& Sianesi, 2003). Similarly, if the authors have panel data and selection is assumed to occur in a time-invariant manner, then fixed effects can be used to alleviate the problem of selection on unobservables. However, because truly time-invariant selection occurs only under a limited set of empirical conditions, authors should strive to complement this approach with other theoretical and empirical justification, and ideally with the other estimation methods mentioned here.

If selection occurs on unobservable variables, and if one can justify that the errors of the selection and outcome equations follow a bivariate normal distribution or find an appropriate instrument, the Heckman method may be an appropriate tool. Hamilton and Nickerson (2003) provide Stata code for estimation of the Heckman method; alternatively, the "Heckman" command may be used. ${ }^{15}$ Given the rise in use of instrumental-variable techniques documented earlier, better understanding of how to find creative and valid instruments may preserve the usefulness of the Heckman method. A more thorough understanding of the need for instruments when using the Heckman method should initiate a search for such instruments in empirical work involving selection.

In particular, researchers should focus their efforts on finding an instrument when possible, accounting for the fact that finding an instrument may be a bit easier than previously thought. For example, Ackerberg and Botticini (2002) provide an interesting econometric approach using interaction terms to create instrumental variables (Ackerberg \& Botticini, 2002). The authors explore the endogenous matching of principals and agents based on unobservable information, making regressions on observable characteristics flawed. They argue that the matching will differ across regions due to different proportions of principals and agents, and thus the regions and regions interacted with observable characteristics can be used as instruments. In addition, many of the papers utilizing sudden exogenous events in their difference-in-difference estimates could explore these events as potential instruments. For example, Siegel (2007) utilized two exogenous shocks in South Korea to analyze the value of political capital. In particular, the first is the unexpected democracy movement and corresponding sudden shift to democracy, and the second is the unexpected Asian financial crisis of 1997-1998 and the resulting shocking, and sudden, shift to the opposition party rule. Thus, careful understanding of the context, as well as unexpected shocks, can be further explored for sources of identification.

Because of the plethora of research techniques possible to deal with endogeneity, we advocate that scholars look more expansively past an almost exclusive reliance on the Heckman two-step method and instead try-especially where the Heckman exclusion restriction cannot be satisfied-to use one or more of the other available research techniques to deal proactively with endogeneity concerns. The Heckman method, when its exclusion restriction cannot be met, often performs even worse than OLS. The solution is not to lose any of the real and valid concern for endogeneity of the last 20 years. Instead, the solution is to leverage the contextual details of the research phenomenon and

\footnotetext{
${ }^{14}$ See Smith and Todd (2001) for an overview of the propensity-score-matching technique. Tucker (2010) compares the Heckman method to the propensity-score-matching technique for purposes of dealing with selection. Clatworthy, Makepeace, and Peel (2009) provide an example from the Accounting literature of replicating prior use of the Heckman method without a valid instrument with propensity-score-matching techniques. Caliendo and Kopeinig (2005) provide guidance on the use of propensity-score-matching techniques.

${ }^{15}$ Alternatively, if researchers have priors about the marginal distribution of the data, a copula approach can be used (Genius \& Strazzera, 2008).
} 
the theory being studied to find better solutions for dealing with endogeneity concerns. The relevant solution may involve greater use of propensity score matching, and/or using interaction terms to create valid instrumental variables (Ackerberg \& Botticini, 2002), and/or relying on exogenous shocks for identification (Siegel, 2007). The ultimate solution is ideally a triangulation approach that leverages the contextual details of the research phenomenon and the theory being studied to find better solutions for dealing with endogeneity concerns.

\section{ACKNOWLEDGEMENTS}

The statistical analysis of firm-level data on U.S. multinational companies was conducted at the Bureau of Economic Analysis (BEA) of the U.S. Department of Commerce under arrangements that maintain legal confidentiality requirements. Views expressed in this paper do not reflect those of the U.S. BEA or the U.S. Department of Commerce. We thank Raymond Mataloni and James Fetzer from the BEA who assisted with the use of this data. We also thank Bill Zeile from the BEA for his helpful comments on the paper. We are grateful to Xiang Ao and Bill Simpson from Harvard Business School for discussions regarding our simulation. We thank the associate editor and the anonymous reviewers for their valuable feedback. Any remaining errors are our own.

\section{REFERENCES}

Ackerberg, D., \& Botticini, M. (2002). Endogeneous matching and the empirical determinants of contract form. Journal of Political Economy, 110(3), 564-591.

Angrist, J., \& Krueger, A. (2001). Instrumental variables and the search for identification: From supply to demand to natural experiments. Journal of Economics Perspectives, 2(4), 69-85.

Antonakis, J., Bendahan, S., Jacquart, P., \& Lalive, R. (2014). Causality and endogeneity: Problems and solutions. In D. V. Day (Ed.), The Oxford handbook of leadership and organizations (Vol. 1, pp. 93-117). Oxford, England: Oxford Library of Psychology.

Bascle, G. (2008). Controlling for endogeneity with instrumental variables in strategic management. Strategic Organization, 6(3), 285-327.

Caliendo, M. \& Kopeinig, S. (2005). Some practice guidance for implementation of propensity score matching (IZA Discussion Paper No. 1588).

Caves, R., \& Mehra, S. (1986). Entry of foreign multinationals into US manufacturing industries. In M. E. Porter (Ed.), Competition in global industries (pp. 449-481). Boston, MA: Harvard Business Press.

Certo, S., Busenbark, J., Woo, H., \& Semadeni, M. (2016). Sample selection bias and Heckman models in strategic management research. Strategic Management Journal, 37(13), 2639-2657.

Chang, S., Kogut, B., \& Yang, J. S. (2016). Global diversification discount and its discontents: A bit of self-selection makes a world of difference. Strategic Management Journal, 37(11), 2254-2274.

Clatworthy, M., Makepeace, G., \& Peel, M. (2009). Selection bias and the big four premium: New evidence using Heckman and matching models. Accounting and Business Research, 39(2), 139-166.

Eberlein, E., \& Keller, U. (1995). Hyperbolic distributions in finance. Bernoulli, 1(3), 281-299.

Geary, R. (1947). Testing for normality. Biometrika, 34, 209-242.

Genius, M., \& Strazzera, E. (2008). Applying the copula approach to sample selection modelling. Applied Economics, 40(11), 1443-1455.

Greene, W. (2008). Econometric analysis (6th ed.). New York, NY: Pearson Prentice Hall.

Hamilton, B., \& Nickerson, J. (2003). Correcting for endogeneity in strategic management research. Strategic Organization, 1(1), $57-78$.

Hartman, R. (1991). A Monte Carlo analysis of alternative estimators in models involving selectivity. Journal of Business and Economic Statistics, 9(1), 41-49.

Heckman, J. (1978). Dummy endogenous variables in a simultaneous equation system. Econometrica, 46(4), 931-959.

Heckman, J. (1979). Sample selection bias as a specification error. Econometrica, 47(1), 153-161.

Hennart, J. F., \& Park, Y. R. (1993). Greenfield vs. acquisition: The strategy of Japanese investors in the United States. Management Science, 39(9), 1054-1070.

Holland, P. W. (1986). Statistics and causal inference. Journal of the American Statistical Association, 81(396), 945-960.

Kenny, D. A. (1979). Correlation and causality. New York, NY: Wiley-Interscience.

Kogut, B., \& Singh, H. (1988). The effect of national culture on the choice of entry mode. Journal of International Business Studies, 19(3), 411-432. 
LaLonde, R. (1986). Evaluating the econometric evaluations of training programs with experimental data. The American Economic Review, 76(4), 604-620.

Larcker, D., \& Rusticus, T. (2010). On the use of instrumental variables in accounting research. Journal of Accounting and Economics, 49, 86-205.

Lee, L. (1983). Generalized econometric models with selectivity. Econometrica, 51(2), 507-512.

Leung, S., \& Yu, S. (1996). On the choice between sample selection and two-part models. Journal of Econometrics, 72, $197-229$.

Leuven, E., \& Sianesi, B. (2003). PSMATCH2: Stata module to perform full mahalanobis and propensity score matching, common support graphing, and covariate imbalance testing. Software.

Little, R. (1985). A note about models for selectivity bias. Econometrica, 53(6), 1469-1474.

Micceri, T. (1989). The unicorn, the normal curve, and other improbable creatures. Psychological Bulletin, 105(1), 156-166.

Murray, M. (2006). Avoiding invalid instruments and coping with weak instruments. Journal of Economic Perspectives, 20(4), $111-132$.

Nelson, F. (1984). Efficiency of the two-step estimator for models with endogenous sample selection. Journal of Econometrics, 24 , 181-196.

Olsen, R. (1980). A least squares correction for selectivity bias. Econometrica, 48(7), 1815-1820.

Puhani, P. (2000). The Heckman correction for sample selection and its critique. Journal of Economic Surveys, 14(1), 53-68.

Shaver, M. (1998). Accounting for Endogeneity when assessing strategy performance: Does entry mode choice affect FDI survival? Management Science, 44, 571-585.

Siegel, J. (2007). Contingent political capital and international alliances: Evidence from South Korea. Administrative Science Quarterly, 52(4), 621-666.

Smith, J., \& Todd, P. (2001). Reconciling conflicting evidence on the performance of propensity-score matching methods. American Economic Review, 91(2), 112-118.

Stolzenberg, R., \& Relles, D. (1997). Tools for intuition about sample selection bias and its correction. American Sociological Review, 62(3), 494-507.

Tucker, J. (2010). Selection bias and econometric remedies in accounting and finance research. Journal of Accounting Literature, 29 , $31-57$.

Tukey, J. W. (1962). The future of data analysis. Annals of Mathematical Statistics, 33, 1-67.

Van de Ven, W., \& Van Praag, B. (1981). The demand for deductibles in private health insurance : A probit model with sample selection. Journal of Econometrics, 17(2), 229-252.

Verbeek, M. (2000). A guide to modern econometrics. West Sussex, England: John Wiley and Sons.

Wagner, J. (1994). The post-entry performance of new small firms in German manufacturing industries. The Journal of Industrial Economics, 42(2), 141-154.

Winship, C., \& Mare, R. (1992). Models for sample selection bias. American Review of Sociology, 18, 327-350.

Zejan, M. C. (1990). New ventures or acquisitions: The choice of Swedish multinational enterprises. The Journal of Industrial Economics, 38(3), 349-355.

\section{SUPPORTING INFORMATION}

Additional supporting information may be found online in the Supporting Information section at the end of the article.

How to cite this article: Wolfolds SE, Siegel J. Misaccounting for endogeneity: The peril of relying on the Heckman two-step method without a valid instrument. Strat Mgmt J. 2019;40: 432-462. https://doi.org/10.1002/smj.2995 